\title{
Integrated Insiders or Alienated Outsiders? How Strong Norms in Organizations Relate to Contractors' Cultural Integration*
}

\author{
Matthew Corritore ${ }^{1}$ and Christos Makridis $^{2}$ \\ ${ }^{1}$ Desautels Faculty of Management, McGill University \\ ${ }^{2}$ Massachusetts Institute of Technology
}

December, 2019

WORKING PAPER

\begin{abstract}
Despite evidence that contract workers are often tightly integrated into organizations' work routines and processes, researchers still do not understand when contractors might be more or less culturally integrated with their organizations. How do the prevailing cultural norms in organizations relate to contract workers' cultural integration? It is unclear whether strong norms are conducive to culturally integrating both regular employees and contractors, workers who may have different cultural preferences, and who differ in status as full versus provisional organizational members. Using data from an employer review website, we examine how norm strength in organizations relates to both contractors' and regular employees' cultural integration. While regular employees exhibit more integration in organizations with stronger norms, we find that norm strength is associated with less integration among contractors, specifically those doing more independent jobs. We also examine whether strong collaborative and strong hierarchical norms appear conducive to integrating contractors versus regular employees. The results have implications for the returns to contracting in organizations, and suggest that organizational cultures face trade-offs in integrating workers across different employment arrangements.
\end{abstract}

${ }^{*}$ We thank Glassdoor for providing the data that we used in this study. We also thank seminar participants at McGill University, and participants at the Berkeley Culture Conference and the American Sociological Association Annual Meeting. The usual disclaimer applies. 
Although contract workers are often thought to maintain distant, "arms-length" relationships with their client organizations (Pfeffer and Baron, 1988; Mayer and Nickerson, 2005), researchers studying contracting now know that some are more tightly integrated into organizational work processes and routines. Organizations often use contract workers and regular employees in similar ways. Contractors frequently work alongside regular employees in the same jobs and as members of the same teams (Ashford et al., 2007; Davis-Blake et al., 2003), perform core organizational tasks (Bidwell, 2010), are managed like regular employees (Barley and Kunda, 2004; Bidwell, 2009), and are sometimes even given central responsibilities for leading and managing other workers (Anderson and Bidwell, 2019).

Despite this more nuanced understanding of how contractors are integrated into the workplace, we still do not understand when contractors might be more or less culturally integrated with their client organizations. Cultural integration, which we define as the extent to which a worker endorses the prevailing cultural norms that guide work in an organization, is thought to benefit both workers and firms. Culturally integrated workers tend to exhibit increased commitment, motivation, and satisfaction (Kristof-Brown et al., 2005) and culturally integrated workforces should experience less conflict and enhanced coordination (Sørensen, 2002; Chatman and O'Reilly, 2016).

Understanding when contracting distances workers from cultural life inside organizations, and any consequences for contractors' welfare, is a core unresolved issue in contracting research (Kunda et al., 2002; Barley and Kunda, 2004; Van Dyne and Ang, 1998), and prior work on related outcomes, such as contractors' commitment to their organizations, has produced mixed findings (Kalleberg and Reynolds, 2003; Thorsteinson, 2003; Pearce, 1993; Guest, 2004). Moreover, studying contractors' cultural integration alongside regular employees' experiences is important precisely because organizations' use of contractors is often blurring, in practice, the distinction between standard and nonstandard workers. As Broschak et al. (2008) argue, understanding how nonstandard workers' attitudes vary is key for assessing whether organizations' efforts to use these workers will yield expected benefits.

In this paper, we examine whether organizations with stronger cultures, cultures thought to 
promote integration among regular employees, are similarly conducive to integrating contractors. We ask: compared to regular employees, how do strong norms in organizations relate to contractors' cultural integration? While all organizations develop a culture, work within some is guided by strong norms, or a defined set of widely shared behaviors and ideas that guide work. One organization's culture, for example, might feature widely shared norms emphasizing slow, deliberate work, while another might feature norms prioritizing speedy execution.

Prior research, which focuses on regular employees, generally assumes a positive association between norm strength and workers' cultural integration (Kotter and Heskett, 1992; O'Reilly and Chatman, 1996). Stronger norms facilitate cultural integration for workers whose cultural preferences are more compatible with those norms, but inhibit integration for those with less compatible preferences (O'Reilly et al., 1991). As such, organizations with strong-norm cultures often strive to cultivate, through member selection and enculturation, a workforce comprised of members who personally endorse the prevailing norms as appropriate or desirable (Deal and Kennedy, 1982). Past work provides little guidance, though, in predicting how strong norms may or may not be conducive to integrating nonstandard workers.

In contrast to regular employees, we propose that stronger norms will tend to impede, rather than enhance, contractors' cultural integration. While strong-norm organizations are often particularly effective at fostering integration among regular employees, there are a number of reasons why their efforts may not extend to contractors, given contractors' status as provisional members of the firm. Moreover, the kinds of workers who enter into contracting likely have different cultural preferences than their regular employee counterparts. If the work styles and behaviors reinforced by strong norms tend to cater to regular employees' preferences, then contractors should exhibit less integration in organizations with stronger norms as compared to organizations with more fragmented cultures.

At the same time, there are reasons to suspect that norm strength may not impede cultural integration for all types of contractors. In particular, we explore whether contractors doing work involving more interpersonal interaction, such as teamwork, respond more favorably to strong-norm 
environments. We also investigate whether particular types of strong norms, namely collaborative and hierarchical norms, are more or less conducive to contractors' cultural integration.

We test these ideas using worker-level data from Glassdoor.com, a leading employer review website. Oft-used methods to study contractors, such as formal surveys and participant observation, are not suited to observing workers across a large, culturally diverse set of organizations. This website allows authenticated workers to anonymously evaluate their organizations' cultures. We

analyze a sample, complete with detailed worker characteristics, of nearly 70,000 contractors and regular employees observed across approximately 4,000 organizations. We measure the strength and content of the prevailing cultural norms in these organizations by analyzing, using a natural language processing technique previously developed using Glassdoor data (Corritore et al., 2019), the free-text cultural descriptions contributed by a much larger set of workers.

To preview our results, we find that norm strength is positively associated with cultural integration for regular employees, but negatively associated with integration for contract workers, specifically contractors doing more independent work. We also find that strong collaborative norms, which might be particularly at odds with contractors' cultural preferences, are no less conducive to fostering cultural integration for contractors than for regular employees, although only workers in teams exhibit higher integration under such norms. However, we find that contractors doing more independent work exhibit higher cultural integration in organizations with strong hierarchical norms, while both regular employees and contractors doing teamwork exhibit less integration in these environments. The findings reveal the types of organizational cultures that are more or less conducive to contractors' cultural integration, and also suggest that organizational cultures face trade-offs in integrating workers across different employment arrangements.

\section{STRONG NORMS AND CULTURAL INTEGRATION}

We define a worker's cultural integration with her organization as the extent to which she endorses, or approves of, the prevailing cultural norms that guide work within the firm. While integration can be conceptualized in different ways (Mobasseri et al., 2019), our definition captures 
the simple idea that some workers more than others embrace the normative order within their organization (Harrison and Carroll, 2006).

Cultural integration can be beneficial for both individuals and organizations. Culturally integrated workers tend to be more committed, motivated, and satisfied (Schneider et al., 2013). Accordingly, organizations with culturally integrated workforces exhibit less conflict and more productivity (Denison and Mishra, 1995; Kreps, 1996; Gordon and DiTomaso, 1992)

The literature on "strong culture" (Kotter and Heskett, 1992; Sørensen, 2002) emphasizes that some organizations strive to maintain a culturally integrated workforce by cultivating strong norms, or a limited set of widely shared behaviors or ideas that guide work (Morris et al., 2015). By widely shared, we mean that most members recognize and work in accordance with these norms.

The presence of strong norms does not necessarily mean that members are highly integrated - members can all acknowledge such norms, yet differ in whether they each endorse them. For example, workers routinely deride strong bureaucratic norms, such as norms emphasizing adherence to formal rules and procedures, even though these norms can strongly influence how work is done.

Nevertheless, we expect a positive association between strong norms in organizations and members' cultural integration, at least among regular employees. Many strong-norm organizations make deliberate efforts, through member selection and enculturation, to ensure members not only recognize and work in accordance with prevailing norms, but also embrace those norms as desirable and appropriate (O’Reilly and Chatman, 1996; Sørensen, 2002). In fact, many purported benefits of cultural strength, such as greater goal alignment, motivation, and commitment among members, hinge on members approving of or buying into the organization's norms (O'Reilly and Chatman, 1996).

Compared to more fragmented cultures, cultures with stronger norms put more emphasis on members' cultural compatibility, which should enhance integration for members with congruent cultural preferences or predispositions, but inhibit integration for misfits. Work on person-organization fit shows that individuals have varying preferences, rooted in personality traits, past experiences, or other factors, for the cultural characteristics of their ideal workplace (Kristof-Brown et al., 
2005). Workers exhibit a higher degree of fit to the extent that their preferences comport with the prevailing norms that guide work within the organization, and fit is positively associated with commitment, attainment, and retention (O'Reilly et al., 1991). By emphasizing adherence to a limited set of norms, strong-norm organizations drive a wedge between those members who fit and those members who do not.

Are strong norm environments similarly conducive to culturally integrating contract workers? Or is norm strength more effective at fostering cultural integration among regular employees than contractors, given contractors' status as provisional members and potentially unique cultural preferences? These theoretical ideas about strong norms and cultural integration were largely developed with standard, full-time members in mind. But as organizations rely more heavily on nonstandard workers, blurring the line in practice between regular and provisional members, it is natural to wonder whether strong norm organizations are effectively integrating contractors and other nonstandard labor.

\section{CONTRACTORS' CULTURAL INTEGRATION}

A central question in contracting research is how contracting might, in some situations, distance workers from cultural life inside client organizations, with negative consequences for worker welfare (Ashford et al., 2007; Pfeffer and Baron, 1988). Some highly-skilled contractors report challenges in learning and adapting to their client firms' differing cultures, and bemoan how their provisional status hinders their integration into social and cultural life within firms (Kunda et al., 2002; Barley and Kunda, 2004). Recent media reports on Google's nonstandard workers, who have expressed discontent with their lack of access to many formal and informal employment perks, are consistent with these accounts. ${ }^{1}$

Beyond its effects on worker welfare, contractors' cultural integration is also important for helping organizations coordinate work. Organizations often use and manage contract workers and regular employees in similar ways, such that contract workers are often tightly integrated into ${ }^{1}$ See, for example, https://www.nytimes.com/2019/05/28/technology/google-temp-workers.html 
organizational work routines and processes. All else equal, contractors who are highly culturally integrated should exhibit a greater ability to coordinate with other members.

To our knowledge, prior work has not studied contractors' cultural integration directly, but research on related outcomes, such as organizational commitment and identification, has produced mixed findings (Guest, 2004; Broschak et al., 2008). For instance, Van Dyne and Ang (1998) found that contractors observed in two service firms exhibited less organizational commitment and engaged in fewer organizational citizenship behaviors than regular employees. In contrast, Pearce (1993) found no differences between contractors and regular employees in their commitment or extrarole behaviors. She attributes this finding to the strong social pressures that contractors face to normatively conform with their teams, pressures which stand in tension with the limited involvement prescribed in their contracts. We consider whether the strength of the prevailing norms in organizations helps explain variance in contractors' cultural integration. Existing work rarely examines organizational-level factors, such as cultural differences, which may be contributing to the mixed findings.

\section{Norm Strength}

While we expect norm strength to be positively associated with regular employees' cultural integration, how might strong norms relate to the level of cultural integration that we observe among contractors? It is tempting to posit that contract workers, like their regular employer counterparts, will exhibit more cultural integration in organizations with stronger norms. Since strong-norm organizations are often adept at selecting compatible members and quickly enculturating them (Rivera, 2012; Harrison and Carroll, 2006), they might be particularly effective at maintaining a highly integrated contractor workforce. Yet, prior research provides hints that contract workers, given their status as provisional members, may face unique barriers to integration in more culturally

intense environments. For example, Kunda et al. (2002), studying highly skilled technical contractors, found that some contractors felt excluded from cultural life, and had difficulty acclimating to new cultures. 
In contrast to regular employees, we expect that contractors will exhibit comparatively less integration in organizations with stronger norms. Although strong-norm organizations often excel at fostering integration among traditional members, formal organizations as a whole may be disincentivized from integrating contract workers. Organizations face legal limits on the extent to which they can control contractors outside of the formal terms stipulated in their contracts (Cappelli and Keller, 2013a; Masten, 1988), and they often take steps to clearly distinguish contractors from regular employees in order to comply with employment law. These steps may entail excluding contractors from onboarding activities and social events that facilitate integration, and selecting, assigning, and managing contractors strictly on the basis of skills and qualifications rather than cultural compatibility.

Additionally, strong-norm cultures may alienate contractors by accentuating contractors' status as provisional members. More intense cultures should draw starker boundaries between members and nonmembers (Eliasoph and Lichterman, 2003; Lamont and Molnár, 2002), making it more difficult for contractors to integrate. Consider, for example, how Google requires its "TVCs" (i.e. temps, vendors, and contractors) to wear different colored badges than regular employees, reifying status differentials between these worker classes.

Furthermore, contractors may be poor cultural fits in strong-norm organizations if their cultural preferences diverge significantly from regular employees' preferences. Contracting can distance workers from and reduce their engagement with organizations (Ashford et al., 2007). Workers might select into contracting because they are attracted to a more "transactional" psychological contract with an organization, as opposed to a standard employment relationship, which is often characterized by broader commitments to coworkers and the firm (Rousseau, 1995). The types of work behaviors and ideas emphasized by strong-norm organizations, such as extra-role behaviors (Pearce, 1993), may align more with regular employees' proclivities. For these reasons, we expect a positive association between norm strength and cultural integration for regular employees, but that this association will be weaker (i.e. less positive or, conversely, more negative) for contractors. 
Hypothesis 1 (H1): The association between norm strength and cultural integration is weaker for contractors than for regular employees.

While we expect that the association between norm strength and cultural integration is weaker for contractors on average, it should be stronger for contractors doing work involving more social interaction, such as teamwork, given the mechanisms we posit. Though contracting is often associated with independent work, many contractors are managed in teams alongside regular employees (Ashford et al., 2007; Davis-Blake et al., 2003; Cappelli and Keller, 2013b), blurring the distinction between these worker classes in practice. We expect that norm strength is more conducive to culturally integrating contractors working in teams than it is for contractors doing more independent work.

There are at least two reasons to expect that contractors working in teams will exhibit comparatively higher levels of cultural integration in organizations with stronger norms. First, these contractors' cultural preferences should, over time, come to more closely resemble those of their peers in the organization. Contractors working in teams have more frequent and intense social interactions with other organizational members - since enculturation occurs in part through peer influence (Harrison and Carroll, 2006; Carley, 1991), these contractors' cultural beliefs and attitudes should gradually be shaped by regular employees' preferences. Second, contractors who sort into jobs requiring teamwork might have more similar cultural preferences as regular employees. Workers select into contracting for many reasons (Bidwell and Briscoe, 2009), not all stemming from a desire to distance oneself from day-to-day organizational life. Compared to contractors attracted to jobs featuring primarily independent work, those in teamwork-intensive positions may have cultural preferences that more comport with norms catering to regular employees, such as deeper commitments to coworkers.

Hypothesis 1a $(\mathrm{H1a})$ : The association between norm strength and cultural integration is stronger for contractors in jobs involving more teamwork. 


\section{How Particular Types of Strong Norms Relate to Contractors' Cultural Integration}

So far, we have argued that stronger, more intense cultural environments facilitate cultural integration for regular workers, yet inhibit integration among contractors, especially those doing independent work. This raises the possibility that strong-norm organizations face an inherent trade-off between culturally integrating regular employees versus integrating contractors, which could limit their ability to effectively use a workforce comprised of both types of workers.

A question that naturally follows is: do some types of strong norms exacerbate this cultural integration gap more than others? Two organizational cultures can feature distinct sets of norms that, while equally strong in the extent to which those norms motivate work, meaningfully differ in their content, or the types of behaviors that they prescribe. Are some strong norms perhaps conducive to integrating both contractors and regular employees? We consider how two types of norms found in many organizations, collaborative norms and hierarchical norms, relate to contractors' and regular employees' cultural integration.

\section{Strong Collaborative Norms}

We define collaborative norms as patterns of thought or behavior that emphasize working in conjunction with others to accomplish tasks, whether through direct teamwork, knowledge seeking and sharing, or other means. Collaborative norms are likely prevalent in many kinds of organizations - many widely-used organizational culture typologies include dimensions related to collaboration (Cameron and Quinn, 2011; O'Reilly et al., 1991). For example, the Organizational Culture Profile asks respondents about several values pertaining to collaboration, such as "working in collaboration with others" and "Being team oriented," and responses to the survey often load onto a "collaborative" dimension (O'Reilly et al., 2014).

By increasing the frequency and intensity of social interactions, and thus exposing contractors to peer influence, strong collaborative norms have the potential to increase cultural integration for contractors and regular employees alike. Collaborative norms could lead to more social interac- 
tions between contractors and regular employees by encouraging knowledge sharing, even between actors that vary in power or status (Srivastava and Banaji, 2011). To the extent that these social interactions extend to contractors, collaborative environments might facilitate cultural integration for both classes of workers.

On the other hand, strong collaborative norms might be particularly at odds with contractors' cultural preferences or predispositions, because some contractors prefer psychological and social distance from their client organizations (Van Dyne and Ang, 1998; Barley and Kunda, 2004). In this way, collaborative environments may be somewhat antithetical to the "transactional" mindset that we typically ascribe to contractors, especially contractors doing more independent jobs.

For these reasons, we anticipate that the association between strong collaborative norms and cultural integration will be weaker for contractors than for regular employees. Again, though, we expect that this association will attenuate for contractors working in teams, who should exhibit higher cultural integration because their cultural preferences are likely more congruent with collaborative ways of working.

Hypothesis 2 (H2): The association between strong collaborative norms and cultural integration is weaker for contractors than for regular employees.

Hypothesis 2a (H2a): The association between strong collaborative norms and cultural integration is stronger for contractors in jobs involving more teamwork.

\section{Strong Hierarchical Norms}

Like collaborative norms, hierarchical norms are present across many organizations. We define hierarchical norms as thoughts or behaviors that reinforce the legitimacy of the unequal distribution of power, roles, and resources (Schwartz, 1999). Such norms often manifest in formal organizations as an emphasis on managerial hierarchy, whereby those in management roles are seen as having 
authority to direct work (Lee and Edmondson, 2017). The Competing Values Framework, one of the most influential cultural typologies, regards hierarchical values and behaviors as a fundamental dimension characterizing a culture's orientation with respect to internal organization (Denison et al., 1991).

We argue that strong hierarchical norms will be particularly conducive to contractors' cultural integration. At first glance, one may suspect that contractors' cultural preferences are incompatible with more hierarchical cultures because of the emphasis that hierarchical norms place on managerial authority. Prior work, mostly focused on high-skilled technical occupations, finds that contractors often bemoan managerial interference (Kunda et al., 2002). Yet, contracting may help workers sidestep such interference - after all, we tend to think that hierarchy is used to manage work that cannot be effectively facilitated through contracts (Williamson, 1981; Mayer and Nickerson, 2005). Additionally, hierarchical cultures are thought to be more rigid and rule-based, and better at supporting workers' efforts to execute on known tasks rather than solve less structured problems (Adler, 2001). As such, organizations with strong hierarchical norms might be a better cultural fit for contractors accustomed to being hired to complete discrete tasks with clearly-defined objectives.

While we expect that the association between strong hierarchical norms and cultural integration is, on average, stronger for contractors than for regular employees, we anticipate that this relationship will attenuate for contractors working in teams. As previously argued, contractors working in teams should have cultural preferences that are more similar to regular employees, and hierarchical norms can depress employees' satisfaction, motivation, and commitment (Lee and Edmondson, 2017). Additionally, contractors working in teams are likely to be managed similarly alongside regular employees, which should make it difficult for them to sidestep burdensome management.

Hypothesis 3 (H3): The association between strong hierarchical norms and cultural integration is stronger for contractors than for regular employees.

Hypothesis 3a (H3a): The association between strong hierarchical norms and cultural integra- 
tion is weaker for contractors in jobs involving more teamwork.

\section{METHOD}

\section{Data Sources and Sample}

We analyze crowdsourced worker-level data from Glassdoor.com. Empirically testing how organizational culture relates to workers' cultural integration is challenging using traditional surveys, because doing so requires detailed data on both workers and firms across a large, diverse set of organizations. We overcome this challenge by analyzing the organization evaluations and descriptions that workers contribute on Glassdoor, a leading employer review website with approximately 17 million users. The site is used by workers primarily to learn about the cultures of different companies. Authenticated workers are incentivized to anonymously provide information about their organizations in exchange for unlocking full access to other organizations' ratings and reviews. Accordingly, nearly all workers provide only one organizational evaluation or review.

Crowdsourced data from online platforms is increasingly being used in management and sociology research to study individuals and organizations (Goldberg et al., 2016; Kovács et al., 2013; Hsu et al., 2009). We follow Corritore et al. (2019) in measuring organizational culture using Glassdoor data and largely the same method.

However, these data differ from those collected via random sampling in that workers self-select into providing information about their organizations. It is important that we consider how this could bias the analysis.

One concern is that workers who are either particularly strong or particularly poor cultural fits could be most likely to evaluate their organizations. Glassdoor mitigates this problem by using a "give to get" model, whereby users are prompted to contribute employer information in exchange

for full site access, which research shows reduces the incidence of extremely positive and negative ratings (Marinescu et al., 2018). In other words, most workers use the site first and foremost to 
gain information about organizations, not to provide ratings and reviews.

Another concern is that contractors who use the site could have incentives to report higher evaluations, on average, than regular employees. For example, it is plausible that employers, despite the anonymity of the evaluations, might coerce contractors to submit positive evaluations in exchange for renewing their contracts. We do not find supporting evidence. We report a robustness check in Table A1 that tests whether workers' evaluations of current versus former employers differs by worker status. If contractors are being coerced to provide positive evaluations, then we should observe contractors providing higher ratings of current clients relative to regular employees. To the contrary, we find that contractors evaluating their current jobs provide comparatively lower ratings.

A related concern is that contractors who use the site are more engaged and committed, on average, than the regular employees contributing on the site. First, we do not think that this is obviously true. Glassdoor freely allows workers across different employment arrangements to evaluate their organizations, and the site is widely known as a general information source about organizational culture and worker attitudes. We acknowledge, though, the possibility that more proactive contractors use the site, the "hired guns" as opposed to the "warm bodies," in Barley and Kunda's (2004) parlance. This would be particularly problematic if we were interested in making absolute claims about how integrated contractors are compared to regular employees. Instead, we focus on comparing how worker integration varies across both organizations with different cultural characteristics and workers in different occupations. These moderation tests should be less sensitive to this type of selection bias stemming from non-random sampling.

Our analytical sample consists of workers who self-report between 2008 and 2015 as either contractors or regular, full-time employees. Contractors comprise approximately $3.5 \%$ percent of the nearly 69,000 workers we observe across almost 4,000 organizations. We observe an average of 35 workers in each firm, though the distribution is skewed - there are a few organizations with many ratings and many organizations with few ratings. The median number of workers observed in a firm is 13 . While the data do not delineate between independent contractors and 
contractors brokered through a staffing agency, the percentage of contractors that we observe is comparable to recent survey evidence (Cappelli and Keller, 2013b). We dropped evaluations linked to firms in the "Staffing and Outsourcing" industry because contractors associated with these firms disproportionately rate their staffing firm rather than their client firm. As expected, contractors are more likely than regular employees to have less than a year of tenure in the firm. We see no significant differences between contractors and regular employees in gender, age, and educational attainment, however.

Workers can evaluate both current and former employers, with ratings of former employers overwhelmingly from workers who departed in the last several months. Among evaluations from regular employees in our analytical sample, approximately 77 percent are of the current employer, as compared to 65 percent among contractors, which is unsurprising given contractors generally exhibit more labor market mobility. We control for whether the evaluation is of a current or former employer in all models. Table A1 in Appendix A includes a robustness check in which we amend our main models by including a term interacting worker status and the current employer indicator. The term is negative and significant only for the culture evaluation outcome, meaning that contractors exhibit lower cultural integration than regular employees when rating their current firm. Its inclusion does not substantively alter any of the results.

Workers in our analytical sample also provided their job titles, which allows us to account for occupational heterogeneity. We linked these job titles to over 220 broad occupational categories in the Bureau of Labor Statistics' Standard Occupational Classification (SOC) system. To do this, we linked job titles to SOC occupation codes using a mapping developed by Liu et al. (2019). Multiple research assistants developed the mapping, and collectively discussed and came to agreement about how to code ambiguous cases.

Figure 1 compares the distributions of contractors versus regular workers across major occupation for our analytical sample. We observe broad coverage across occupation, although regular workers are more highly concentrated in management and sales occupations, while contractors are more highly concentrated in occupational classes such as computers/mathematics, arts and 
entertainment, and education.

All of our models include at least broad occupation fixed effects, meaning we compare outcomes within rather than between these occupational categories. Figure 2 compares the distributions of contractors versus regular workers by firm sector. Both types of workers are broadly represented across sectors, though with some notable differences. Regular workers are more highly represented in retail and food services, while contractors more highly represented in information technology and education sectors. We include detailed industry fixed effects in all models.

\section{MEASURES-DEPENDENT VARIABLES}

We measure a worker's cultural integration with her organization using two measures: her overall rating of the organization, and her rating of the organization's culture and values. ${ }^{2}$ Glassdoor prompts workers to provide an "overall rating" of the organization, as well as a rating of the organization's "culture and values," both on a 1-5 scale, where 5 is the highest rating. The website is broadly known for capturing workers' assessments of organizational culture. Accordingly, these two measures are highly correlated, with a correlation coefficient of 0.76 .

Figure 3 shows frequency plots of the overall and culture ratings. The overall rating has a slight left skew, with a modal rating of 4 , but neither the lowest (1) nor highest (5) ratings are disproportionately represented. The culture rating is more highly clustered around ratings of one and five.

\section{MEASURES-INDEPENDENT VARIABLES}

\section{Contractor Status}

We set a dummy variable to 1 if the worker is working on contract, or 0 if the worker is a regular employee.

\section{Norm Strength}

\footnotetext{
${ }^{2}$ The culture rating is only available for 2012 to 2015 .
} 
We adopt an organization-level measure of norm strength developed by Corritore et al. (2019), which they calculated using Glassdoor data from the same time period. The premise of the measure is that one can detect the linguistic signatures of cultural norms in the language that workers use when describing their organizations to others, in this case when they write free text pro and con Glassdoor reviews of their organizations. Once we have detected the norms in each review, we can assess to what degree all reviewers within a given organization/year describe the organization with reference to the same norms. More agreement indicates that the set of norms is stronger, in the sense that they are more widely shared among workers. While our analytical sample includes approximately 70,000 worker evaluations with a complete set of worker characteristics, we create our organizational culture measures using a much larger set of approximately 1.5 million free text reviews.

We follow Corritore et al. (2019) in training a Latent Dirichlet Allocation topic model on phrases that make explicit references to the word culture or a synonym across all reviews on the site, producing a set of cultural topics (ex. collaboration, entrepreneurial, meritocratic, etc.). Appendix B includes more details on topic modeling and the procedure used. We then fit this model to reviews of the organizations that appear in our analytic sample, identifying the cultural topics that workers mention in each review.

We operationalize norm strength as the similarity of cultural topics that workers mention across reviews, with similarity measured as one minus the average pairwise Jensen-Shannon distance between the cultural topic vectors for all reviews in a given firm/year. The measure is only computed for firms with at least 25 reviews in a given year. For illustration, a firm with strong norms might feature most workers talking about the culture's emphasis on teamwork, or aggressiveness, or some combination of other topics. We expect norm strength to exhibit high persistence year-to-year, and indeed the within-firm $t-1$ lag measure is correlated with the measure at time $t$ at 0.72 . Corritore et al. (2019) provide several other measure validity checks. It is important to emphasize that the cultural dimensions produced by the topic model are trained on and applied to both the pro and con review text. Consequently, the topics are relatively agnostic with respect to the valence of the 
review, in that they do not simply capture the sentiments of reviewers who either strongly approve or disapprove of a particular norm.

We decided to use all available text reviews of the organizations in our analytical sample in calculating our culture measures. This includes review text from some of the workers that also provide overall and culture/values ratings used in our analysis. Approximately 81 percent of the regular employee and 74 percent of the contractors in our analytical sample also contributed written comments used to calculate the organizational level culture measures. However, these observations represent on average only 4.1 percent (s.d. 4.5 percent) of the total text reviews across organization/year spells used to calculate the organizational culture measures. Nevertheless, we checked whether variance in the overlap between ratings and text comments is distorting the norm strength measure for some organization/years in ways that could impact our estimates, by including a measure of the overlap as a control in all models in Table A1. The coefficient is positive but insignificant for the overall rating, but positive and significant (at $p<0.05$ ) for the culture and values rating in some models. However, all the models produce substantively identical results including this control, giving us confidence that our findings are not being driven by this potential distortion.

\section{Strong Collaborative Norms}

We identified organization/years with strong collaborative norms using a variant of our topic modeling approach. We started with a 65 topic solution manually pruned by Corritore et al. (2019) to combine redundant topics and to remove topics that were difficult to interpret. The highest weighted words for each of the 65 topics are listed in Table C1. Among those 65 topics is one that Corritore et al. (2019) labeled "teamwork," which most closely describes collaborative norms, with stems for words like team, support, collaborate, and cooperate.

We coded a given organization/year observation as having strong collaborative norms if this topic was frequently and consistently discussed across reviews, consistent with the idea that these norms are intensely held and widely shared. Formally, a strong collaboration firm is one in which the probability weight devoted to the "teamwork" topic is above the median among all organi- 
zation/year observations, and the coefficient of variation (the standard deviation relative to the mean) across the reviews is below the median among all organization/year observations.

\section{Strong Hierarchical Norms}

We identified organization/years with strong hierarchical norms using the same procedure as for strong collaborative norms, except using the topic that Corritore et al. (2019) labeled "hierarchy," with highly weighted stems for words such as manage, level, upper, senior, execute, lower, and direct. The collaborative and hierarchical indicators show less persistence over time than the norm strength measure, both correlated within firm from $t-1$ to $t$ at 0.34 . In Table A2, we tested our main models using culture measures averaged over all available years for each organization, and find largely identical results.

\section{Teamwork}

We measure whether workers' jobs tend to feature teamwork using an occupational level measure provided by the Occupational Information Network ( $\left.\mathrm{O}^{*} \mathrm{NET}\right)$, the leading source of information about occupations in the United States. The O*NET teamwork measure asks "How important is it to work with others in a group or team in this job?," rated on a 1-7 scale. The ratings were initially based on responses from subject matter experts within each occupation, but are regularly updated via worker surveys. We delineated between high and low teamwork occupations using a median split. In our analytical sample, approximately 80 percent of regular employees and 60 percent of contractors are in high teamwork occupations.

\section{ANALYTICAL STRATEGY AND ESTIMATION}

Our worker level data contain workers within occupations and organizations. In our tests of the association between norm strength and our outcomes, we include some 220 detailed occupation fixed

effects at the 5 digit SOC code level, allowing us to compare contractors and regular employees doing ostensibly the same work. In our tests comparing workers in high and low teamwork occupations, 
we instead include 23 broad occupational classes at the 2 digit SOC code level. These models allow us to compare detailed occupations within these broad classes that vary in the amount of teamwork required.

We include a number of worker, occupational, and organizational controls. Only a small minority of workers are observed more than once in the data, so we rely on individual covariates to partially account for meaningful differences across workers, namely age, gender, educational attainment, tenure in the organization, the log of their earnings, and whether the worker is rating a current or former job. Beyond the occupational fixed effects previously discussed, we also control for $\mathrm{O}^{*} \mathrm{NET}$ ratings of the technical, cognitive, social, and manual skills required in each occupation, as well as indicators based on the $\mathrm{O}^{*} \mathrm{NET}$ ratings of whether the occupation requires unstructured versus structured work, and whether work involves high levels of coordination and leadership. At the organizational level, we control for firm size using the log of the number of employees, the log of the number of Glassdoor reviews used to calculate the organizational culture measures, and include 141 industry fixed effects using Glassdoor's industry taxonomy. All models include year fixed effects, all standard errors are clustered by organization, and we estimate all models using OLS.

\section{RESULTS}

Table 1 provides summary statistics, which reflect the sample's skew towards more educated workers in higher skilled occupations. 63 percent of the evaluations are from workers whose highest educational attainment is a bachelor's degree, and the mean occupation requires above average levels of technical, cognitive, and social skill, and below average level of manual skill.

Table 2 shows bivariate correlations (educational attainment, tenure, and age are excluded for readability). The overall rating and the culture and values rating are highly correlated at 0.76, suggesting that workers' overall evaluations are strongly related to their assessments of the organization's culture. Reported earnings has a modest positive correlation with both outcome measures. The current job indicator is correlated at 0.25 and 0.21 with the overall and culture ratings, respectively. Unsurprisingly, contractors have less tenure in the organization, and are less 
likely to be in occupations involving teamwork or coordinating and leading others.

Among the occupational level variables, the unstructured work and coordinating/leading others indicators have a high positive correlation. High coordination and high teamwork also have a moderate positive correlation. Finally, the unstructured work, coordination, and teamwork indicators are each positively correlated with the cognitive and social skill measures, and negative correlated with the manual skill measure.

Among the organizational level variables, norm strength has little correlation with the outcomes, but the strong collaborative norms measure is positively associated with and the strong hierarchical norms measure negatively associated with both outcome measures.

The models in Table 3 test hypothesis 1, that, compared to regular employees, the association between norm strength and cultural integration is less positive (i.e. more negative) for contractors. All the models in Table 3 include 5 digit SOC code occupation fixed effects. In model 1, contractors provide higher overall ratings, and there is a positive but marginally significant norm strength effect. Among the controls, ratings are lower in larger organizations, women provide lower ratings, and those evaluating their current organization provide higher ratings. Model 2 replaces the overall rating outcome with the culture rating. As might be expected, norm strength has a stronger association with the culture rating.

Models 3 and 4 interact the contractor indicator and the norm strength measure for the overall and culture rating outcomes, respectively. In both models, the interaction term is negative and significant. In model 3 , the norm strength effect is negative and marginally significant for contractors $(-0.09, p=0.052)$, while positive and significant for regular employees $(0.03, p=0.036)$, and these two estimates are statistically different from each other. In model 4 , the norm strength effect is negative but insignificant for contractors $(-0.03, p=0.558)$, while positive and significant for regular employees $(0.10, p=0.000)$, and again these estimates are statistically different from each other. We plot the predicted outcomes for models 3 and 4 in Panel A and B, respectively, in Figure 4. Both models predict that the association between norm strength and cultural integration is weaker for contractors than for regular employees as norm strength increases. Together, these 
results provide support for hypothesis 1.

In Table 4, we test how these norm strength effects vary across occupations involving more or less teamwork. To do so, we replace the finer grained occupation fixed effects with major occupation fixed effects at the two digit SOC code level, and compare fine grained occupations within these major categories. Since we shift from within to between occupation models, we add controls for the level of technical, cognitive, social, and manual skill characteristic of each occupation, as well as indicators denoting occupations featuring more unstructured work, and work involving coordination and/or leadership duties. Since workers with technical skills may prefer contracting as a way to avoid burdensome management (Barley and Kunda, 2004), we also interact the contract indicator with the technical skills rating.

Models 1 and 2 replicate models 3 and 4 in Table 3 using this between occupation framework. Models 1 and 2 again provide support for hypothesis 1 - contractors provide lower relative evaluations as a function of increasing norm strength. Among the control variables, unstructured work is associated with higher evaluations, and high teamwork occupations are associated with lower evaluations. Additionally, more manual skill requirements predict lower evaluations in some specifications.

Since teamwork is likely more conducive to collaborative cultures, we add our indicator measure of strong collaborative norms in Models 3 and 4, as well as an interaction term between collaborative norms and high teamwork occupations. Collaborative norms are associated with higher evaluations, with some evidence that collaborative norms boost evaluations for those in high teamwork occupations.

Finally, models 5 and 6 test H1a, that the association between norm strength and contractors' cultural integration is more positive (i.e. less negative) for contractors in jobs involving teamwork. If so, we would expect a positive coefficient for the three way interaction between contractor status, norm strength, and high teamwork. The interaction term is positive and significant for the overall outcome in model 7 . The norm strength effect is negative and significant for contractors in low teamwork occupations $(-0.31, p=0.000)$, while indistinguishable from zero for the other groups 
(and the estimate for low teamwork contractors is statistically different from the estimates for the other three groups).

We plot the predicted outcomes for contractors versus regular employees in both high and low teamwork occupations in Figure 5, panel A. The norm strength effect is relatively flat for contractors in high teamwork occupations and for regular employees in low and high teamwork occupations. However, the norm strength effect is negative for contractors in low teamwork occupations. Turning to the culture rating outcome in model 8 , the three way interaction is positive but insignificant. The norm strength effect is negative and marginally significant for low teamwork contractors $(-0.19$, $p=0.065)$, but positive for high teamwork regular workers $(0.09, p=0.000)$, and these estimates are significantly different from each other. We plot the predicted outcomes for this model in panel B of Figure 5. Together, these results provide some support for hypothesis H1a.

In table 5 , we test hypothesis 2 , that the association between strong collaborative norms and cultural integration is weaker for contractors than for regular employees. Models 1 and 2 interact collaborative norms with contract status. The positive effect of strong collaborative norms is not moderated by contract status, providing no support for hypothesis 2 . Models 3 and 4 add an interaction between strong collaborative norms and teamwork. Consistent with prior models, we find some evidence that collaborative norms boost ratings for workers in high teamwork occupations. Finally, models 5 and 6 include the three-way interaction between collaborative norms, high teamwork occupations, and contract status, which is insignificant in both models.

We plot predicted outcomes for these models in Figure 6 . We find some positive and significant effects of strong collaborative norms for workers in teams. However, we find no support for hypotheses 2 or $2 \mathrm{a}$ - we do not find that the association between strong collaborative norms and cultural integration is weaker for regular employees, and this association is not anymore stronger for contractors doing teamwork than it is for regular workers in teams.

One possible reason for these null results is that the effect of collaborative norms on contractors' cultural integration could operate through two channels, each with opposite effects that cancel the other out. Contractors working more independently may not fit as well a priori in cultures with 
strong collaborative norms. Nonetheless, they may become more enculturated over time as they have more frequent peer interactions in such organizations.

In table 6 , we test hypothesis 3 , that compared to regular employees, contractors in organizations with strong hierarchical norms exhibit higher cultural integration than those in organizations lacking such norms. Models 1 and 2 show that strong hierarchical norms are associated with less integration overall. Models 3 and 4 interact the hierarchical norms indicator with worker status. In support of hypothesis 3, we find that contractors provide higher, and regular employees lower, evaluations in organizations with more hierarchical cultures, although the interaction term is only marginally significant for the culture rating. In models 5 and 6 , we test hypothesis $3 \mathrm{a}$, that the association between strong hierarchical norms and cultural integration is less positive for contractors in jobs involving more teamwork. We find strong support, as indicated by the positive and significant three-way interaction terms between worker status, hierarchical norms, and high teamwork. The effect of hierarchical norms for contractors in low teamwork occupations is positive and significant for both outcomes, while negative and significant for all other groups.

We plot the predicted outcomes for the overall and culture outcomes in Panels A and B in Figure 6. The clear pattern is that contractors doing more independent work respond favorably to more hierarchical norms, while regular employees and contractors in high team occupations respond negatively.

\section{Robustness Checks}

We report robustness checks in Appendix A. In Table A1, we rerun our focal models including two additional controls. First, we interact contract status with the current job indicator to account for any differing incentives that current contractors may face to contribute an evaluation. For example, employers might pressure contractors to provide favorable evaluations in exchange for contract renewal. We also control for a variable measuring the percentage of the workers in our analytical sample within the organization that also provide text reviews used in calculating the organizational culture measures, to check whether workers providing both evaluations and reporting 
on the norms in the organization is biasing the results. The contractor $\mathrm{X}$ current job interaction term is negative and significant in some models, meaning that current contractors tend to provide lower evaluations. The percentage workers with text reviews variable is positive and significant in some specifications. However, the results are substantively identical with inclusion of these controls.

In Table A2, we checked whether temporal instability in the organization level culture measures is driving the results. We generally expect organizational culture to be highly persistent over time. Our norm strength measure at time $t$ is highly correlated at time $t-1$ within organization at 0.72 . However, our collaborative and hierarchical norms indicators show less persistence over time, with correlations between $t$ and $t-1$ of 0.34 for both measures. We created pooled versions of these measures by averaging their values within organization across time. The results are substantively identical using these pooled measures, giving us confidence that, while noisy, our measures are capturing the presence of cultural norms.

In Table A3, we rerun the collaborative norm models in Table 5 using an alternative measure of collaboration based on the "team excellence" topic in the LDA models instead of the "teamwork" topic. The results are largely substantively identical, giving us confidence that any idiosyncrasies of the teamwork topic are not driving the results.

Lastly, we rerun the core models in Table A4, but this time excluding evaluations from workers in management occupations. We do so for two reasons. First, managers are highly overrepresented in the data for regular employees as compared to contractors. Second, contractors with management responsibilities may be more integrated in the firm in ways that could be driving the results. The results are substantively identical.

\section{DISCUSSION}

How do strong cultural norms in organizations relate to contractors' cultural integration relative to regular employees? Given mounting evidence that organizations often use contract workers and traditional employees in similar ways, it is natural to wonder whether cultures thought to promote workforce integration among standard employees are also conducive to culturally integrating 
contractors. The answer could further our understanding of when contracting distances workers from cultural life inside organizations, a core unresolved issue in contracting research. We find that strong workplace norms, which many organizations strive to cultivate to enhance coordination and performance, are associated with higher cultural integration among regular employees but lower cultural integration among contractors, particularly for contractors doing more independent work. Additionally, while we find no evidence that strong collaborative norms inhibit integration for contractors, we find that they are only associated with enhanced integration for workers in teams. Finally, strong hierarchical norms are conducive to cultural integration for more independent contractors, although they are associated with reduced cultural integration for both contractors doing teamwork and regular employees.

The findings show that the cultural context, together with the nature of the work performed, are important for predicting whether these nonstandard workers will exhibit the ability to culturally integrate with their client organizations. Since culturally integrated workers tend to experience higher welfare, the findings highlight cultural factors that help predict when workers experience positive returns from nonstandard work arrangements, versus when workers in such arrangements might experience alienation and estrangement at work. Moreover, the results also underscore a tension between, on one hand, contractors' technical integration into core work routines and processes, and on the other, organizations' ability to culturally integrate some nonstandard workers alongside traditional members. Organizations may struggle to leverage a mixed workforce of standard and nonstandard workers if they face difficulty fostering high levels of cultural integration across workers.

\section{Contract Workers' Cultural Integration and Welfare}

Our study contributes to the contracting literature by showing that contractors can vary in how culturally integrated they are with their client organizations, in part due to differences in organizational culture and the type of work that they perform. A recurring theme in this literature, based on evidence primarily from highly skilled information technology contractors, is that contract workers, as provisional members, can face challenges interfacing with social and cultural life inside 
organizations (Barley and Kunda, 2004; Van Dyne and Ang, 1998). Observing contractors across a diverse array of occupations and organizations, we show that contractors' cultural experiences vary significantly with the strength and content of an organization's prevailing cultural norms, and that these relationships are moderated by whether contractors work in teams. Despite our expanding awareness that organizations often broadly rely on contractors to complete central tasks, contractors can experience varying levels of cultural integration with client firms as a function of organizational culture.

An obvious implication is that contract workers and organizations could benefit from attending to how organizational culture impacts contractors' cultural experiences on the job. Contract workers doing more independent jobs, for example, might generally avoid organizations with particularly strong cultures, unless those organizations feature strong hierarchical norms. In contrast, contractors' doing teamwork might seek out cultures with strong norms more generally, especially those emphasizing collaboration. Likewise, organizations might put more emphasis on cultural fit when hiring contract workers and assigning them to tasks and teams, especially if they rely on these nonstandard workers to perform core tasks that require higher degrees of coordination with other members.

Another important theoretical implication is that contracting, and likely the kinds of workers who select into such arrangements, might in some ways be less compatible with strong culture workplaces. We show that contractors, particularly those doing more independent work, exhibit lower cultural integration as a function of increasing norm strength. While we can only speculate in this paper about the underlying mechanisms, future research could pinpoint precisely why contracting arrangements or contract workers might be at odds with strong culture organizations. Workers who select into contracting to do more independent work could fit poorly with strong cultures, cultures which on average might emphasize less mechanistic or procedural behaviors in favor of more interpersonal, idiosyncratic, or extrarole ones. Or contractors working independently might be more alienated or socially ostracized in strong cultures that draw starker distinctions between insiders and outsiders. 
Regardless of the underlying mechanisms, this study helps us better understand the consequences of organizations integrating contract labor into their core work routines and processes (Bidwell, 2009, 2010; Davis-Blake et al., 2003). Organizations might benefit from outsourcing important tasks to independent contractors, but companies with stronger cultures might not realize these benefits if those contractors struggle to coordinate with other members and perform well due to cultural integration challenges. However, we also show that not all types of strong norms depress cultural integration for these more independent contractors - they exhibit more integration in organizations with strong hierarchical norms, although all other workers exhibit less integration. The clear implication is that organizations with hierarchical cultures might have an advantage in effectively using more independent contractors.

Our finding that contractors doing teamwork respond more positively to strong norms also has implications for contracting research. It may be difficult for firms to use contract labor for work done in teams, given the complexity involved in monitoring and verifying individual contractors' performance when completing interdependent tasks (Mayer and Nickerson, 2005). Nevertheless, we know that many contractors are managed in teams alongside regular employees (Ashford et al., 2007; Davis-Blake et al., 2003), and Cappelli and Keller (2013b) were surprised to find that organizations with more team-based jobs also use more nonstandard workers. Our results suggest that, rather than being excluded from cultural life (Barley and Kunda, 2004), contractors doing teamwork are able to culturally integrate in strong-culture organizations. Again, we cannot pinpoint whether this is due to worker-organization fit or other processes, such as enhanced enculturation through peer influence. Nonetheless, future research should examine whether these cultural integration benefits outweigh any costs of using contract labor to complete more interdependent tasks. If there are net benefits, then organizations with strong-norm cultures might focus on using contractors for team-based tasks, while organizations with weaker norms might effectively use more independent contractors.

Our study also demonstrates that non-pecuniary job rewards can vary for contractors doing different kinds of work inside different types of organizations. We observe that contractors derive 
different levels of value depending on the nature of the work they perform in different types of organizational cultures. The results suggest that the mixed findings in prior work comparing contractors and regular employees along related outcomes, such as organizational commitment, may be in part attributable to between-firm differences in contractors' experiences (Kalleberg and Reynolds, 2003; Thorsteinson, 2003; Pearce, 1993; Guest, 2004; Cappelli and Keller, 2013b). A continued focus on examining differences in the ways that firms use nonstandard workers, and any impacts on workers themselves, is a promising avenue for future research (Bidwell et al., 2013).

We also contribute to the broader literature on nonstandard workers' welfare by showing that contractors' cultural integration, which is linked to broader well-being, varies by occupational and organizational cultural characteristics (Kalleberg, 2000; Spreitzer et al., 2017; Broschak et al., 2008; Briscoe et al., 2011). We build on prior work that highlights differences in workers' skills and job autonomy to explain when nonstandard work arrangements are more or less conducive to worker welfare (Spreitzer et al., 2017; Kalleberg, 2003). Comparing workers using similar skills in the same occupations, we show that organizational culture helps explain variance in contractors' cultural integration, echoing recent calls for more attention on how firm-level factors shape nonstandard work outcomes (Cappelli and Keller, 2013b; Bidwell et al., 2013). Our results imply that practitioners concerned about nonstandard workers' inclusion inside organizations should worry less about those contractors embedded within teams, and more about those working in relative isolation.

\section{Organizational Culture and Nonstandard Work}

Our study also demonstrates that there is fertile ground for advances at the intersection of work on organizational culture and employment research examining firms' use of nonstandard workers. Foundational theories of organizational culture were developed largely with standard employees in mind, and perhaps for good reason - strong cultures are often associated with a high degree of buyin and commitment from members, characteristics which we do not typically ascribe to contractors and other nonstandard workers. However, many organizations with strong cultures also rely on a mixed workforce composed of standard and nonstandard workers, calling into question whether 
these cultural influences are conducive to fostering integration for all members.

Google is a salient example. In late 2018, over 20,000 Google workers participated in a mass walkout, in part to protest the company's handling of sexual harassment allegations against top executives. ${ }^{3}$ Contract workers and other nonstandard workers, who purportedly comprise more than half of Google's workforce, and often work alongside regular employees on similar tasks, participated in the protests. ${ }^{4}$ One of the protesters' demands was an end to a "two-tier system" that they claim privileges regular employees as cultural insiders, but treats contract and temporary workers as cultural outsiders who are denied access to the many formal and informal benefits of standard employment. ${ }^{5}$

We suspect that this example is not an outlier, given our sense that many companies known for their strong cultures also outsource many tasks to nonstandard workers. And our study potentially corroborates this account by showing a wide divergence between contractors' and regular employees' cultural integration in cultures with stronger norms. To the extent that strong norms at Google are impeding some nonstandard workers from integrating, or are in some way less congruent with these workers' cultural preferences, then the relationships that we uncover could help explain the Google case. A promising avenue for future research is to use finer-grained case comparison methods to investigate how and why nonstandard workers' cultural experiences vary across organizations with different cultural orientations.

Our study also contributes to the strong culture literature by suggesting that it might be difficult for organizations with strong norms to effectively use workers spanning different employment arrangements. Prior work asks whether strong cultures, which tend to feature less diversity in norms, values, and beliefs, facilitate coordination and productivity at the expense of creativity, innovation, and adaptability (Sørensen, 2002; Kotrba et al., 2012; Corritore et al., 2019). Our study suggests that one downside of less-diverse strong norm environments is that they can restrict the kinds of workers who fit and/or amplify status distinctions between perceived insiders and outsiders, which

\footnotetext{
${ }^{3}$ https://www.theverge.com/2018/11/2/18057716/google-walkout-20-thousand-employees-ceo-sundar-pichai-meeting ${ }^{4}$ https://www.nytimes.com/2019/05/28/technology/google-temp-workers.html

${ }^{5}$ https://twitter.com/GoogleWalkout/status/1110990194390589442?s=20
} 
can undermine an organization's ability to leverage a mixed workforce of standard and nonstandard workers. Future work might examine whether cultural strength has implications for diversity along other important dimensions, such as gender, race, or functional background.

By showing that collaborative and hierarchical norms have varying relationships with cultural integration across different sets of workers, our study also builds on work exploring how particular types of norms and beliefs impact workers' experiences (Nishii, 2013; Schneider et al., 2013). Future research could investigate how other types of norms, or particular combinations of norms, relate to the level of cultural integration exhibited by standard versus nonstandard workers. Our results suggest that combining elements of both collaborative and hierarchical norms can foster integration for both contractors working in teams and contractors working more independently. However, none of the norms we examined boosted cultural integration for all types of workers in our study. There may be some norms that help integrate a wide variety of workers. For example, to the extent that status disparities are driving some of the divergence we observe between contractors and regular employees, norms surrounding inclusive behaviors and attitudes might help integrate workers from different employment arrangements (Nishii, 2013).

\section{Limitations and Future Directions}

This study has a number of limitations that suggest opportunities for future research. First, we rely on workers' self reported ratings of the organization and its culture as cultural integration measures. While a worker's evaluation of the culture likely reflects her fit with it, these measures limit our ability to identify the precise mechanisms driving the relationships that we show. Is low cultural integration being driven by a mismatch between the worker's cultural preferences and the organization's prevailing cultural norms? Or are other factors, such as status differences between standard and nonstandard workers that are magnified in strong cultures, driving some of the divergence we observe between regular employees and contractors? Our results suggest that status differences are not impeding cultural integration for all contractors, but rather that some contractors have different cultural preferences than regular employees. For instance, we 
find that contractors working in teams respond to cultural norms similarly to regular employees, despite their contractor status. Moreover, more independent contractors report higher cultural integration than contractors doing teamwork in organizations with strong hierarchical norms, which is more consistent with variance in cultural preferences. Future work could directly measure how contractors' cultural preferences differ from other workers using tools such as the Organizational Culture Profile (O'Reilly et al., 1991). There is also a promising opportunity for researchers to use qualitative methods to identify the precise mechanisms driving the differences between contractors' and regular employees' cultural experiences inside firms.

Second and related, we only observe the outcome of a labor market matching process between workers and organizations. Consequently, we cannot disentangle to what degree our results are driven by workers and organizations selecting one another, versus caused by interpersonal dynamics within organizations. Nor can we attribute the results to some causal effect of contracting, independent of the preferences and predispositions of the workers who selected into these work arrangements. Regardless, our observations that some types of contractors exhibit comparably low cultural integration in particular cultures highlight the contexts in which scholars might be particularly concerned about the potentially substandard returns to contracting (Kalleberg et al., 2000). Moreover, the outcomes of these person-organization matching processes are central to the development and maintenance of organizational culture (Harrison and Carroll, 2006). Future research could begin to assess whether these workers might be better off in another job, organization, or work arrangement by analyzing data that follows workers over time as they transition between arrangements.

Third, we rely on workers self-selecting into providing ratings and reviews on the Glassdoor website to generate the data that we both analyze and use for calculating our organizational culture measures. We control for a detailed set of worker characteristics in an effort to partially account for worker selection into providing an evaluation, and we do not find evidence that contractors' motivation to evaluate differs meaningfully from regular employees'. Additionally, our measures of strong norms are relatively stable over time, consistent with our theoretical expectation that 
organizational culture is highly time-persistent, which bolsters our confidence in the measures (Corritore et al., 2019). Nonetheless, we cannot completely reject the possibility that non-random selection is biasing our estimates of the associations between worker status, organizational culture characteristics, and cultural integration. Future research might replicate and extend these results using a random sample of workers, or leverage longitudinal data to conduct within-worker analyses.

\section{CONCLUSION}

When contract workers are cultural insiders versus outsiders inside their client organizations is a core issue in contracting research, and important for understanding nonstandard work's impact on worker welfare. This study finds that key characteristics of an organization's culture, namely the strength and content of prevailing norms, are important predictors of contractors' cultural integration vis-à-vis regular employees. It can be difficult for a given organizational culture to facilitate cultural integration for both contract workers and regular employees, even though organizations often use standard and nonstandard workers in similar ways to do comparable work. Future work should continue investigating how the differences between standard and nonstandard workers pose a challenge for organizations seeking gains from a blended workforce. 


\section{FIGURES}

Figure 1: Frequency Distributions of Contractors and Regular Employees by Major Occupation

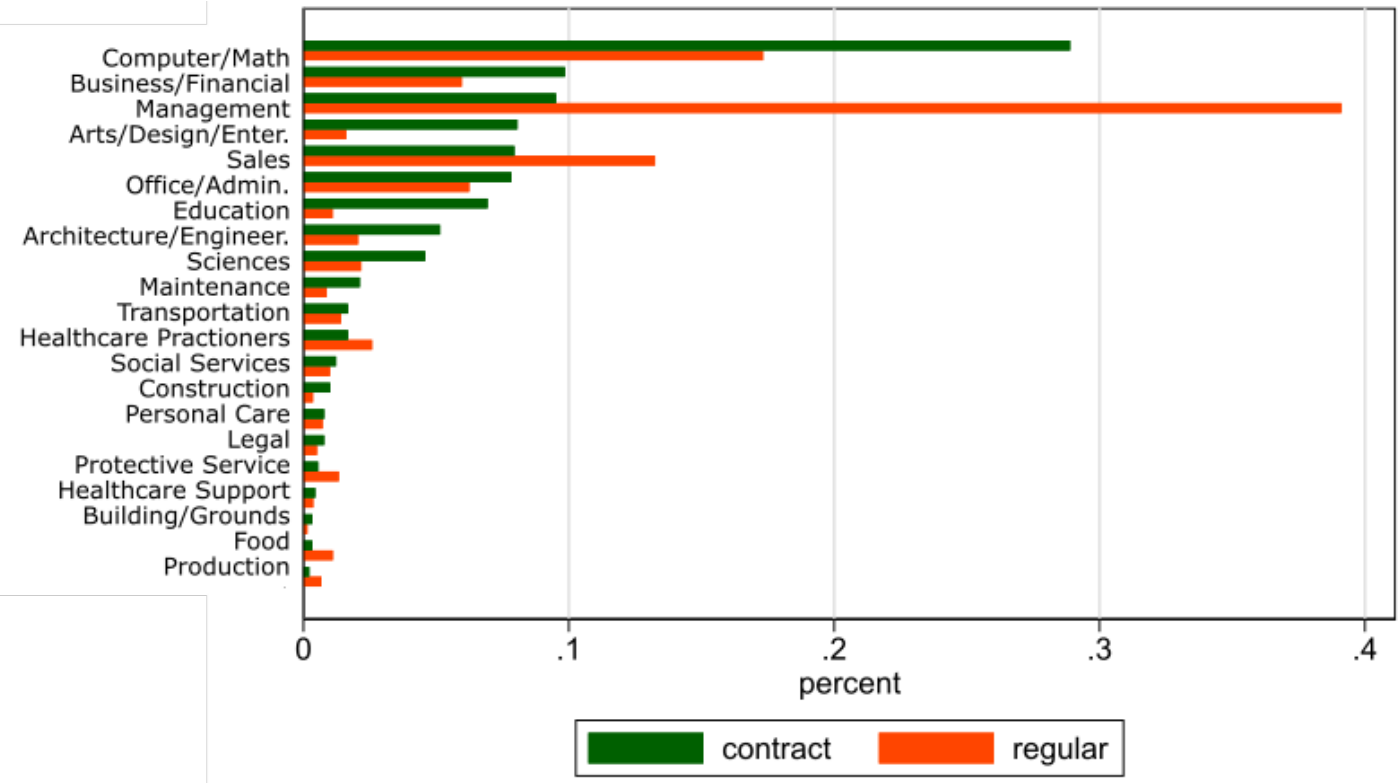


Figure 2: Frequency Distributions of Contractors and Regular Employees by Sector

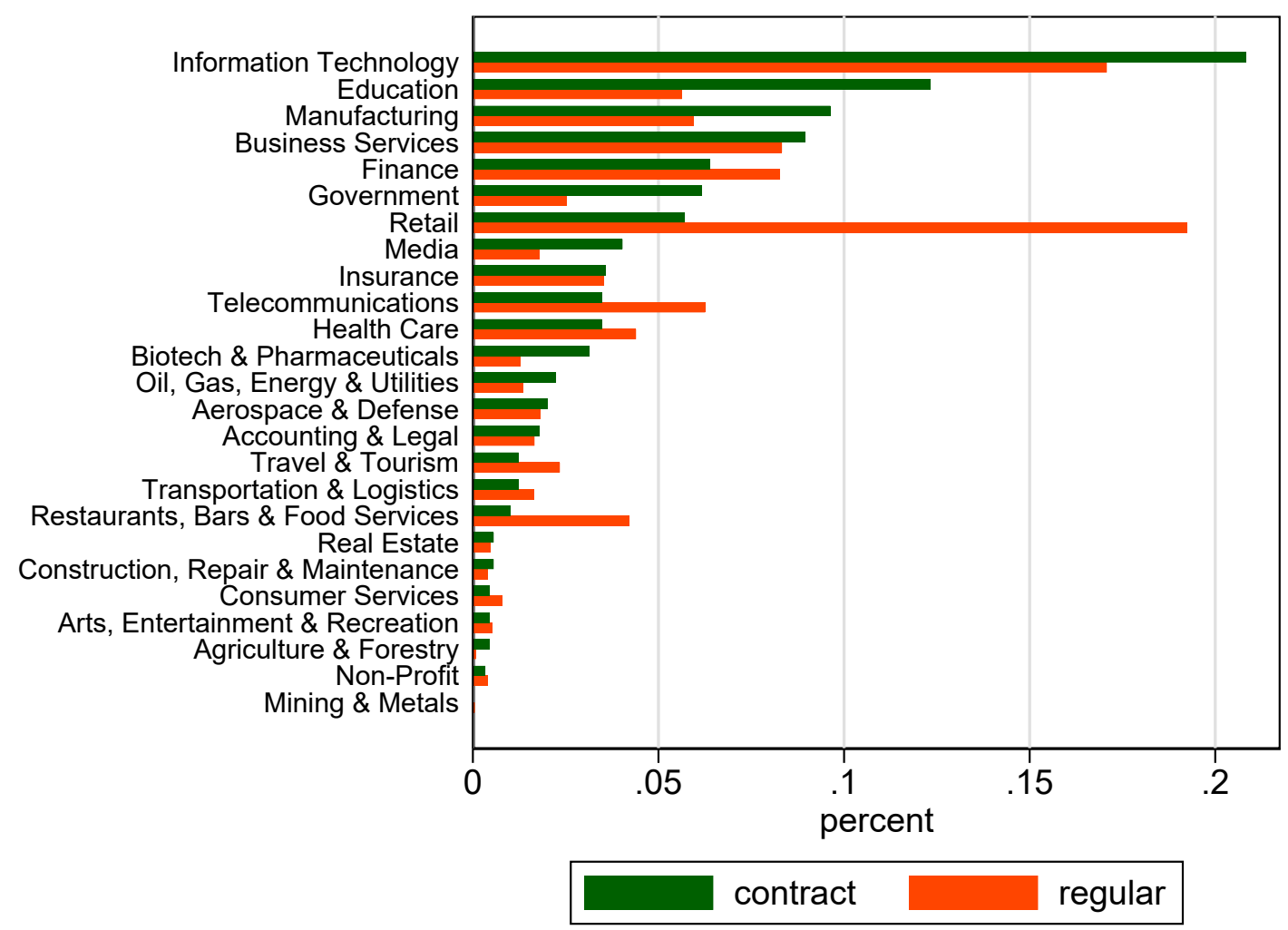

Figure 3: Distributions of Cultural Integration Measures
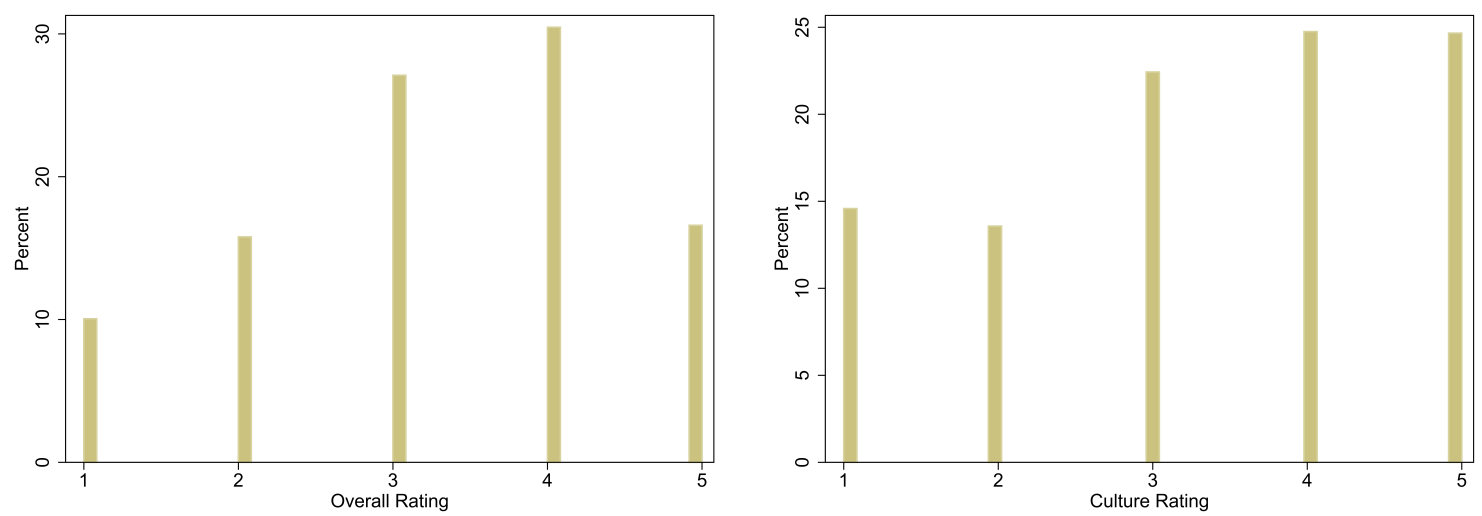
Figure 4: Predicted Cultural Integration by Norm Strength and Worker Status

overall rating

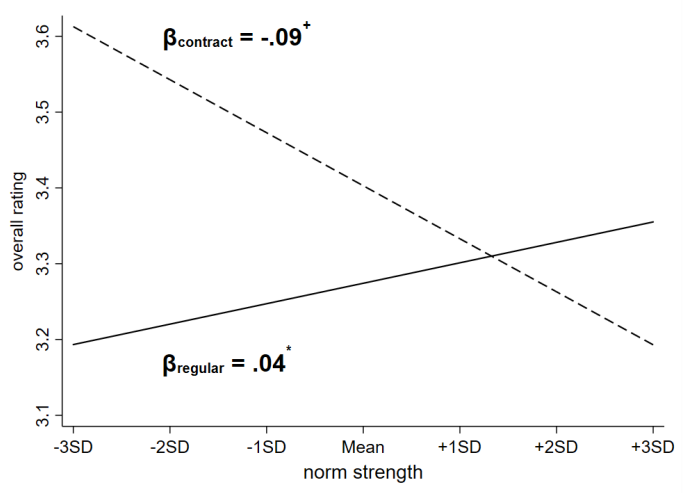

culture rating

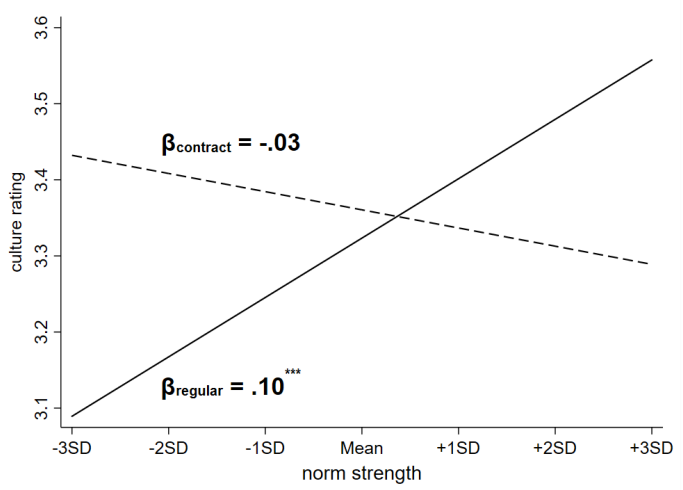

Notes. Predicted overall rating from Table 3, Model 3. Predicted culture rating from Table 3, Model 4. Interaction effect estimates and standard errors are calculated using Stata's margins command.

$+p<0.10,{ }^{*} p<0.05,{ }^{* *} p<0.01, * * * p<0.001$

Figure 5: Predicted Cultural Integration by Norm Strength and Worker Status/Teamwork

overall rating

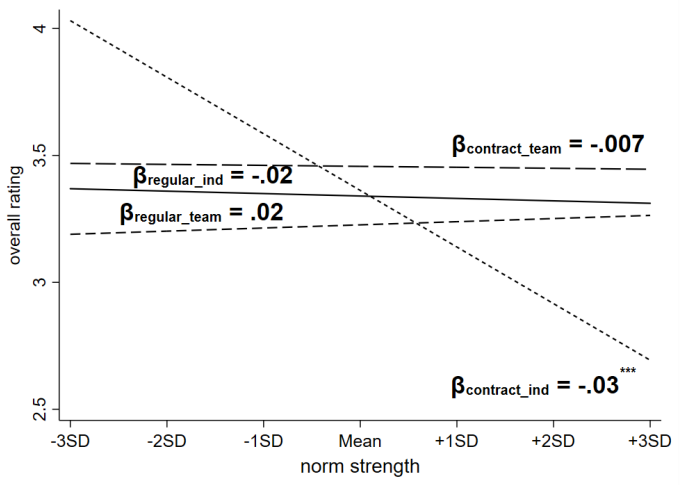

culture rating

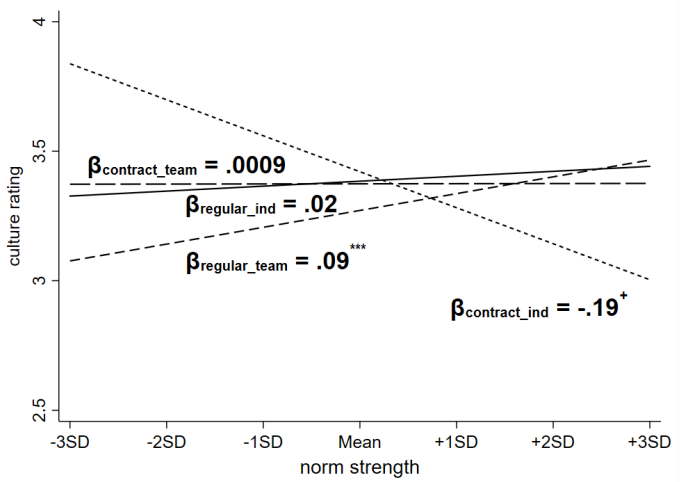

Notes. Predicted overall rating from Table 4, Model 5. Predicted culture rating from Table 4, Model 6. Interaction effect estimates and standard errors are calculated using Stata's margins command.

$+p<0.10, * p<0.05, * * p<0.01, * * * p<0.001$ 
Figure 6: Predicted Cultural Integration by Collaborative Norms and Worker Status/Teamwork
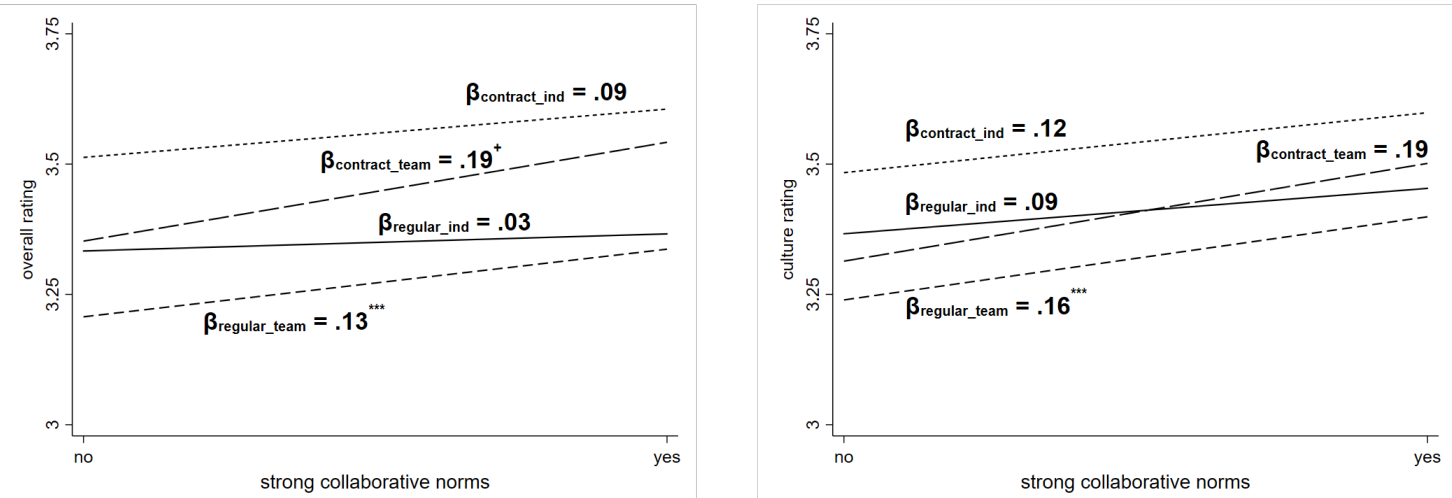

Notes. Predicted overall rating from Table 5, Model 5. Predicted culture rating from Table 5, Model 6. Interaction effect estimates and standard errors are calculated using Stata's margins command.

$+p<0.10,{ }^{*} p<0.05, * * p<0.01, * * * p<0.001$

Figure 7: Predicted Cultural Integration by Hierarchical Norms and Worker Status/Teamwork
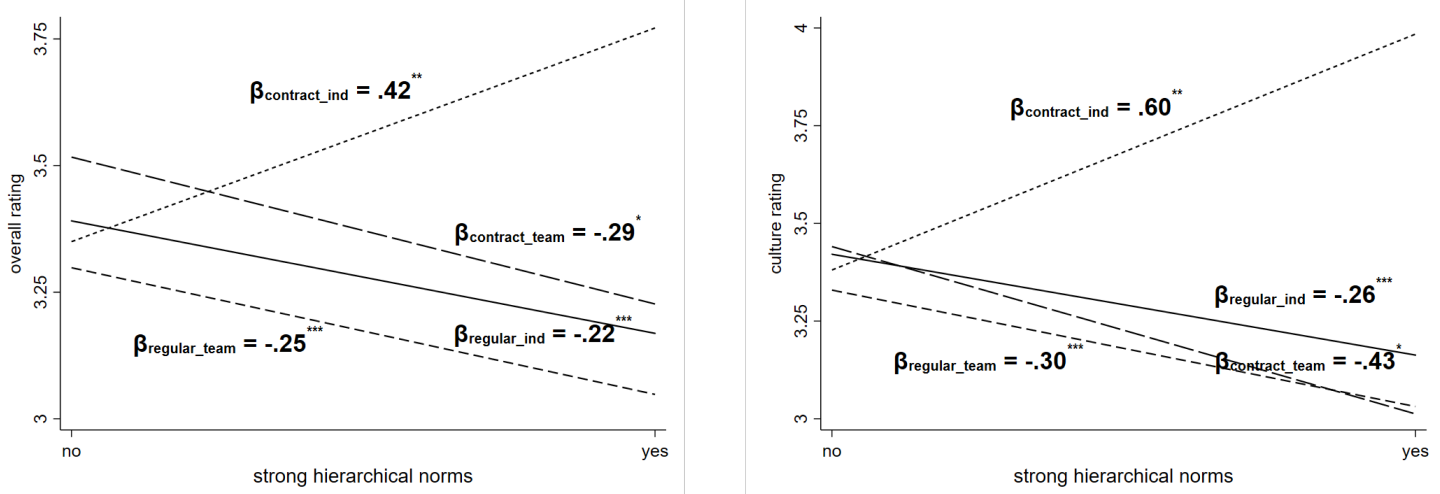

Notes. Predicted overall rating from Table 6, Model 5. Predicted culture rating from Table 6, Model 6. Interaction effect estimates and standard errors are calculated using Stata's margins command.

$+p<0.10,{ }^{*} p<0.05,{ }^{* *} p<0.01,{ }^{* * *} p<0.001$ 


\section{TABLES}

Table 1: Summary Statistics

\begin{tabular}{lcccc}
\hline \hline & mean & sd & min & max \\
\hline Overall Rating & 3.28 & 1.23 & 1.00 & 5.00 \\
Culture Rating & 3.29 & 1.37 & 1.00 & 5.00 \\
Contractor & 0.02 & 0.15 & 0.00 & 1.00 \\
Norm Strength & -0.26 & 0.69 & -2.45 & 11.37 \\
Collaborative Norms & 0.16 & 0.36 & 0.00 & 1.00 \\
Hierarchical Norms & 0.20 & 0.40 & 0.00 & 1.00 \\
Log of Number Reviews & 5.35 & 1.34 & 3.22 & 8.17 \\
Log of Number Employees & 9.98 & 2.01 & 0.00 & 14.60 \\
Unstructured Occ. & 0.65 & 0.48 & 0.00 & 1.00 \\
High Coordination Occ. & 0.55 & 0.50 & 0.00 & 1.00 \\
High Teamwork Occ. & 0.80 & 0.40 & 0.00 & 1.00 \\
Technical Skills & 0.52 & 1.10 & -2.49 & 2.65 \\
Cognitive Skills & 0.49 & 0.73 & -2.74 & 1.85 \\
Social Skills & 0.87 & 0.92 & -2.09 & 2.32 \\
Manual Skills & -0.59 & 0.59 & -1.55 & 3.03 \\
Female & 0.37 & 0.48 & 0.00 & 1.00 \\
Log Wage & 10.76 & 0.65 & -0.09 & 13.19 \\
High School & 0.13 & 0.34 & 0.00 & 1.00 \\
Associates & 0.03 & 0.17 & 0.00 & 1.00 \\
Bachelors & 0.63 & 0.48 & 0.00 & 1.00 \\
MBA & 0.02 & 0.13 & 0.00 & 1.00 \\
PhD/MD & 0.01 & 0.10 & 0.00 & 1.00 \\
Tenure: <1 & 0.14 & 0.35 & 0.00 & 1.00 \\
Tenure: 1-2 & 0.25 & 0.44 & 0.00 & 1.00 \\
Tenure: 3-4 & 0.19 & 0.39 & 0.00 & 1.00 \\
Tenure: 5-7 & 0.14 & 0.35 & 0.00 & 1.00 \\
Tenure: 8-10 & 0.06 & 0.24 & 0.00 & 1.00 \\
Tenure: 10+ & 0.10 & 0.30 & 0.00 & 1.00 \\
Age & 34.77 & 10.80 & 13.00 & 113.00 \\
Current Job & 0.75 & 0.43 & 0.00 & 1.00 \\
\hline Observations & 47157 & & & \\
\hline \hline & & & & \\
\hline
\end{tabular}




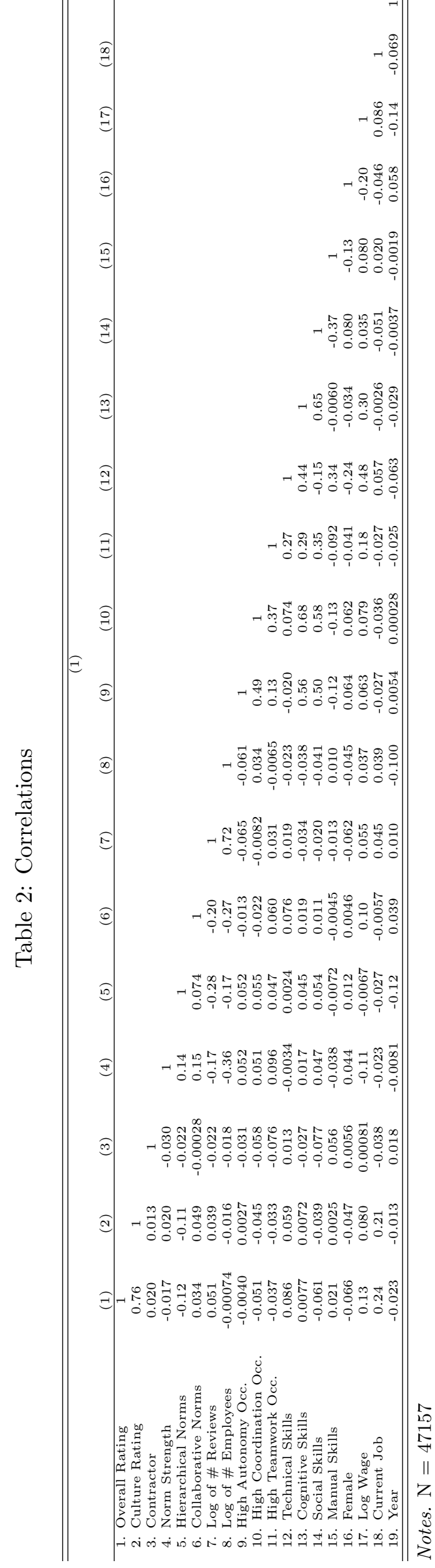


Table 3: Predicting Cultural Integration by Contracting and Norm Strength

\begin{tabular}{|c|c|c|c|c|}
\hline & $\begin{array}{c}\text { (1) } \\
\text { Overall Rating }\end{array}$ & $\begin{array}{c}(2) \\
\text { Culture Rating }\end{array}$ & $\begin{array}{c}\text { (3) } \\
\text { Overall Rating }\end{array}$ & $\begin{array}{c}(4) \\
\text { Culture Rating }\end{array}$ \\
\hline \multirow[t]{2}{*}{ Contractor } & $0.091^{*}$ & 0.0058 & 0.047 & -0.049 \\
\hline & $(2.50)$ & $(0.14)$ & $(1.14)$ & $(1.04)$ \\
\hline \multirow[t]{2}{*}{ Norm Strength } & $0.033^{+}$ & $0.10^{* * *}$ & $0.037^{*}$ & $0.11^{* * *}$ \\
\hline & $(1.88)$ & $(4.69)$ & $(2.10)$ & $(4.84)$ \\
\hline \multirow[t]{2}{*}{ Contractor $\times$ Strength } & & & $-0.13^{* *}$ & $-0.14^{*}$ \\
\hline & & & $(2.69)$ & $(2.51)$ \\
\hline \multirow[t]{2}{*}{ Log of Number Employees } & $-0.028^{* * *}$ & $-0.027^{* *}$ & $-0.028^{* * *}$ & $-0.027^{* *}$ \\
\hline & $(3.37)$ & $(2.85)$ & $(3.41)$ & $(2.89)$ \\
\hline \multirow[t]{2}{*}{ Log of Number Reviews } & $0.072^{* * *}$ & $0.075^{* * *}$ & $0.073^{* * *}$ & $0.075^{* * *}$ \\
\hline & $(4.97)$ & $(4.58)$ & $(5.02)$ & $(4.62)$ \\
\hline \multirow[t]{2}{*}{ Log Wage } & $0.26^{* * *}$ & $0.18^{* * *}$ & $0.26^{* * *}$ & $0.18^{* * *}$ \\
\hline & $(13.76)$ & $(8.52)$ & $(13.76)$ & $(8.51)$ \\
\hline \multirow[t]{2}{*}{ Female } & $-0.051^{* * *}$ & $-0.062^{* * *}$ & $-0.051^{* * *}$ & $-0.062^{* * *}$ \\
\hline & $(4.33)$ & $(4.37)$ & $(4.32)$ & $(4.37)$ \\
\hline \multirow[t]{2}{*}{ High School } & $0.047^{*}$ & -0.031 & $0.046^{*}$ & -0.031 \\
\hline & $(2.27)$ & $(1.22)$ & $(2.25)$ & $(1.24)$ \\
\hline \multirow[t]{2}{*}{ Associates } & 0.0067 & -0.041 & 0.0059 & -0.042 \\
\hline & $(0.26)$ & (1.02) & $(0.23)$ & (1.04) \\
\hline \multirow[t]{2}{*}{ Bachelors } & 0.018 & 0.011 & 0.018 & 0.011 \\
\hline & (1.37) & $(0.65)$ & $(1.35)$ & $(0.63)$ \\
\hline \multirow[t]{2}{*}{ MBA } & $-0.11^{* * *}$ & $-0.13^{* *}$ & $-0.11^{* * *}$ & $-0.13^{* *}$ \\
\hline & $(3.67)$ & $(3.08)$ & $(3.67)$ & $(3.08)$ \\
\hline \multirow[t]{2}{*}{$\mathrm{PhD} / \mathrm{MD}$} & -0.020 & -0.025 & -0.019 & -0.025 \\
\hline & $(0.53)$ & $(0.49)$ & $(0.51)$ & $(0.48)$ \\
\hline \multirow[t]{2}{*}{ Tenure: 1-2 } & $0.032^{+}$ & 0.015 & $0.031^{+}$ & 0.014 \\
\hline & $(1.75)$ & $(0.66)$ & $(1.70)$ & $(0.61)$ \\
\hline \multirow[t]{2}{*}{ Tenure: $3-4$} & 0.021 & 0.010 & 0.021 & 0.0098 \\
\hline & $(1.07)$ & $(0.43)$ & (1.07) & $(0.41)$ \\
\hline \multirow[t]{2}{*}{ Tenure: $5-7$} & 0.032 & 0.0029 & 0.032 & 0.0025 \\
\hline & (1.43) & $(0.11)$ & $(1.43)$ & $(0.09)$ \\
\hline \multirow[t]{2}{*}{ Tenure: 8-10 } & 0.024 & -0.018 & 0.025 & -0.018 \\
\hline & $(0.89)$ & $(0.55)$ & $(0.90)$ & $(0.55)$ \\
\hline \multirow[t]{2}{*}{ Tenure: $10+$} & $0.12^{* * *}$ & 0.052 & $0.12^{* * *}$ & 0.052 \\
\hline & $(4.29)$ & (1.60) & $(4.32)$ & (1.61) \\
\hline \multirow[t]{2}{*}{ Age } & $-0.011^{* * *}$ & $-0.011^{* * *}$ & $-0.011^{* * *}$ & $-0.011^{* * *}$ \\
\hline & $(14.79)$ & $(13.76)$ & $(14.80)$ & $(13.77)$ \\
\hline \multirow[t]{2}{*}{ Current Job } & $0.57^{* * *}$ & $0.59^{* * *}$ & $0.57^{* * *}$ & $0.59^{* * *}$ \\
\hline & $(34.99)$ & $(33.48)$ & $(35.00)$ & $(33.50)$ \\
\hline \multirow[t]{2}{*}{ Constant } & 0.24 & $1.28^{* * *}$ & 0.25 & $1.28^{* * *}$ \\
\hline & $(0.88)$ & $(4.10)$ & $(0.91)$ & $(4.12)$ \\
\hline $\mathrm{N}$ & 68602 & 55715 & 68602 & 55715 \\
\hline
\end{tabular}

$\overline{\text { Notes. Absolute } t \text { statistics are in parentheses. All models include detailed occupation, industry, and year fixed }}$ effects. Standard errors are clustered by organization.

${ }^{+} p<0.10,{ }^{*} p<0.05,{ }^{* *} p<0.01,{ }^{* * *} p<0.001$ 
Table 4: OLS Models Predicting Cultural Integration by Contracting, Norm Strength, and Teamwork

\begin{tabular}{|c|c|c|c|c|c|c|}
\hline & $\begin{array}{c}(1) \\
\text { Overall }\end{array}$ & $\begin{array}{c}(2) \\
\text { Culture }\end{array}$ & $\begin{array}{c}(3) \\
\text { Overall }\end{array}$ & $\begin{array}{c}(4) \\
\text { Culture }\end{array}$ & $\begin{array}{c}(5) \\
\text { Overall }\end{array}$ & $\begin{array}{c}(6) \\
\text { Culture }\end{array}$ \\
\hline Contractor & $\begin{array}{c}0.12^{*} \\
(1.98)\end{array}$ & $\begin{array}{c}0.044 \\
(0.65)\end{array}$ & $\begin{array}{c}0.12^{*} \\
(2.00)\end{array}$ & $\begin{array}{c}0.046 \\
(0.68)\end{array}$ & $\begin{array}{c}-0.050 \\
(0.67)\end{array}$ & $\begin{array}{c}-0.014 \\
(0.15)\end{array}$ \\
\hline Norm Strength & $\begin{array}{l}0.014 \\
(0.70)\end{array}$ & $\begin{array}{c}0.081^{* *} \\
(3.26)\end{array}$ & $\begin{array}{l}0.011 \\
(0.60)\end{array}$ & $\begin{array}{c}0.078^{* *} \\
(3.18)\end{array}$ & $\begin{array}{c}-0.013 \\
(0.47)\end{array}$ & $\begin{array}{l}0.026 \\
(0.72)\end{array}$ \\
\hline Contract $\times$ Strength & $\begin{array}{l}-0.14^{*} \\
(2.00)\end{array}$ & $\begin{array}{l}-0.16^{*} \\
(2.31)\end{array}$ & $\begin{array}{l}-0.13^{*} \\
(1.97)\end{array}$ & $\begin{array}{l}-0.16^{*} \\
(2.29)\end{array}$ & $\begin{array}{c}-0.29^{* * *} \\
(3.64)\end{array}$ & $\begin{array}{l}-0.22^{*} \\
(2.22)\end{array}$ \\
\hline Collaborative Norms & & & $\begin{array}{l}0.029 \\
(0.61)\end{array}$ & $\begin{array}{l}0.080 \\
(1.38)\end{array}$ & $\begin{array}{c}0.034 \\
(0.73)\end{array}$ & $\begin{array}{l}0.094 \\
(1.63)\end{array}$ \\
\hline Teamwork $\times$ Collaborative & & & $\begin{array}{l}0.096^{*} \\
(1.99)\end{array}$ & $\begin{array}{l}0.069 \\
(1.20)\end{array}$ & $\begin{array}{c}0.088^{+} \\
(1.83)\end{array}$ & $\begin{array}{l}0.052 \\
(0.89)\end{array}$ \\
\hline Contract $\times$ Teamwork & & & & & $\begin{array}{c}0.32^{* * *} \\
(3.41)\end{array}$ & $\begin{array}{c}0.13 \\
(1.15)\end{array}$ \\
\hline Teamwork $\times$ Strength & & & & & $\begin{array}{l}0.030 \\
(1.24)\end{array}$ & $\begin{array}{c}0.063^{+} \\
(1.89)\end{array}$ \\
\hline Contract $\times$ Teamwork $\times$ Strength & & & & & $\begin{array}{c}0.27^{*} \\
(2.52)\end{array}$ & $\begin{array}{c}0.13 \\
(1.01)\end{array}$ \\
\hline Log of Number Employees & $\begin{array}{c}-0.033^{* * *} \\
(3.58)\end{array}$ & $\begin{array}{c}-0.034^{* *} \\
(3.01)\end{array}$ & $\begin{array}{c}-0.031^{* * *} \\
(3.31)\end{array}$ & $\begin{array}{c}-0.031^{* *} \\
(2.73)\end{array}$ & $\begin{array}{c}-0.032^{* * *} \\
(3.42)\end{array}$ & $\begin{array}{c}-0.031^{* *} \\
(2.77)\end{array}$ \\
\hline Log of Number Reviews & $\begin{array}{c}0.080^{* * *} \\
(4.82)\end{array}$ & $\begin{array}{c}0.087^{* * *} \\
(4.48)\end{array}$ & $\begin{array}{c}0.084^{* * *} \\
(5.21)\end{array}$ & $\begin{array}{c}0.092^{* * *} \\
(4.87)\end{array}$ & $\begin{array}{c}0.085^{* * *} \\
(5.29)\end{array}$ & $\begin{array}{c}0.093^{* * *} \\
(4.92)\end{array}$ \\
\hline High Teamwork Occ. & $\begin{array}{c}-0.091^{* * *} \\
(3.75)\end{array}$ & $\begin{array}{c}-0.11^{* * *} \\
(4.10)\end{array}$ & $\begin{array}{c}-0.10^{* * *} \\
(4.11)\end{array}$ & $\begin{array}{c}-0.12^{* * *} \\
(4.21)\end{array}$ & $\begin{array}{c}-0.10^{* * *} \\
(3.84)\end{array}$ & $\begin{array}{c}-0.10^{* *} \\
(2.97)\end{array}$ \\
\hline Unstructured Occ. & $\begin{array}{c}0.086^{* * *} \\
(4.55)\end{array}$ & $\begin{array}{c}0.086^{* * *} \\
(3.44)\end{array}$ & $\begin{array}{c}0.089^{* * *} \\
(4.69)\end{array}$ & $\begin{array}{c}0.089^{* * *} \\
(3.58)\end{array}$ & $\begin{array}{c}0.089^{* * *} \\
(4.72)\end{array}$ & $\begin{array}{c}0.089^{* * *} \\
(3.59)\end{array}$ \\
\hline High Coordination Occ. & $\begin{array}{c}0.018 \\
(0.72)\end{array}$ & $\begin{array}{c}-0.014 \\
(0.51)\end{array}$ & $\begin{array}{l}0.020 \\
(0.80)\end{array}$ & $\begin{array}{c}-0.013 \\
(0.45)\end{array}$ & $\begin{array}{c}0.019 \\
(0.79)\end{array}$ & $\begin{array}{c}-0.013 \\
(0.45)\end{array}$ \\
\hline Technical Skills & $\begin{array}{l}0.012 \\
(0.58)\end{array}$ & $\begin{array}{l}0.010 \\
(0.38)\end{array}$ & $\begin{array}{l}0.011 \\
(0.55)\end{array}$ & $\begin{array}{c}0.0090 \\
(0.34)\end{array}$ & $\begin{array}{l}0.012 \\
(0.60)\end{array}$ & $\begin{array}{c}0.0086 \\
(0.33)\end{array}$ \\
\hline Cognitive Skills & $\begin{array}{r}-0.050 \\
(1.58)\end{array}$ & $\begin{array}{c}-0.012 \\
(0.29)\end{array}$ & $\begin{array}{l}-0.049 \\
(1.57)\end{array}$ & $\begin{array}{c}-0.010 \\
(0.26)\end{array}$ & $\begin{array}{l}-0.051 \\
(1.63)\end{array}$ & $\begin{array}{r}-0.013 \\
(0.32)\end{array}$ \\
\hline Social Skills & $\begin{array}{c}0.040^{+} \\
(1.67)\end{array}$ & $\begin{array}{l}0.051 \\
(1.61)\end{array}$ & $\begin{array}{c}0.038 \\
(1.58)\end{array}$ & $\begin{array}{l}0.048 \\
(1.52)\end{array}$ & $\begin{array}{c}0.038 \\
(1.58)\end{array}$ & $\begin{array}{l}0.047 \\
(1.50)\end{array}$ \\
\hline Manual Skills & $\begin{array}{c}-0.037^{*} \\
(2.23)\end{array}$ & $\begin{array}{l}-0.027 \\
(1.21)\end{array}$ & $\begin{array}{c}-0.038^{*} \\
(2.29)\end{array}$ & $\begin{array}{l}-0.028 \\
(1.27)\end{array}$ & $\begin{array}{c}-0.037^{*} \\
(2.23)\end{array}$ & $\begin{array}{l}-0.027 \\
(1.24)\end{array}$ \\
\hline Contract $\times$ Technical Skills & $\begin{array}{l}-0.029 \\
(0.82)\end{array}$ & $\begin{array}{c}-0.042 \\
(0.96)\end{array}$ & $\begin{array}{l}-0.030 \\
(0.84)\end{array}$ & $\begin{array}{c}-0.043 \\
(0.98)\end{array}$ & $\begin{array}{c}-0.068^{+} \\
(1.96)\end{array}$ & $\begin{array}{l}-0.058 \\
(1.33)\end{array}$ \\
\hline Constant & $\begin{array}{c}0.30 \\
(1.31)\end{array}$ & $\begin{array}{c}1.21^{* * *} \\
(4.55)\end{array}$ & $\begin{array}{c}0.33 \\
(1.42)\end{array}$ & $\begin{array}{c}1.23^{* * *} \\
(4.63)\end{array}$ & $\begin{array}{c}0.33 \\
(1.44)\end{array}$ & $\begin{array}{c}1.21^{* * *} \\
(4.58)\end{array}$ \\
\hline$\overline{\mathrm{N}}$ & 57562 & 47157 & 57562 & 47157 & 57562 & 47157 \\
\hline
\end{tabular}

Notes. Absolute $t$ statistics are in parentheses. All models include all individual controls, as well as major occupation, industry, and year fixed effects. Standard errors are clustered by organization.

${ }^{+} p<0.10,{ }^{*} p<0.05,{ }^{* *} p<0.01,{ }^{* * *} p<0.001$ 
Table 5: OLS Models Predicting Cultural Integration by Contracting, Collaborative Norms, and Teamwork

\begin{tabular}{|c|c|c|c|c|c|c|}
\hline & $\begin{array}{c}(1) \\
\text { Overall }\end{array}$ & $\begin{array}{c}(2) \\
\text { Culture }\end{array}$ & $\begin{array}{c}(3) \\
\text { Overall }\end{array}$ & $\begin{array}{c}(4) \\
\text { Culture }\end{array}$ & $\begin{array}{c}(5) \\
\text { Overall }\end{array}$ & $\begin{array}{c}(6) \\
\text { Culture }\end{array}$ \\
\hline Contractor & $\begin{array}{l}0.15^{* *} \\
(2.66)\end{array}$ & $\begin{array}{l}0.091 \\
(1.47)\end{array}$ & $\begin{array}{l}0.15^{* *} \\
(2.62)\end{array}$ & $\begin{array}{l}0.089 \\
(1.45)\end{array}$ & $\begin{array}{l}0.040 \\
(0.50)\end{array}$ & $\begin{array}{l}0.040 \\
(0.43)\end{array}$ \\
\hline Collaborative Norms & $\begin{array}{c}0.12^{* * *} \\
(4.52)\end{array}$ & $\begin{array}{c}0.15^{* * *} \\
(4.84)\end{array}$ & $\begin{array}{l}0.033 \\
(0.70)\end{array}$ & $\begin{array}{c}0.087 \\
(1.56)\end{array}$ & $\begin{array}{l}0.035 \\
(0.74)\end{array}$ & $\begin{array}{c}0.082 \\
(1.44)\end{array}$ \\
\hline Hierarchical Norms & $\begin{array}{c}-0.24^{* * *} \\
(11.33)\end{array}$ & $\begin{array}{c}-0.29^{* * *} \\
(10.80)\end{array}$ & $\begin{array}{c}-0.24^{* * *} \\
(11.32)\end{array}$ & $\begin{array}{c}-0.29^{* * *} \\
(10.80)\end{array}$ & $\begin{array}{c}-0.24^{* * *} \\
(11.32)\end{array}$ & $\begin{array}{c}-0.29^{* * *} \\
(10.80)\end{array}$ \\
\hline Contract $\times$ Collaborative & $\begin{array}{l}0.047 \\
(0.43)\end{array}$ & $\begin{array}{c}0.019 \\
(0.14)\end{array}$ & $\begin{array}{l}0.060 \\
(0.55)\end{array}$ & $\begin{array}{l}0.028 \\
(0.21)\end{array}$ & $\begin{array}{l}-0.012 \\
(0.05)\end{array}$ & $\begin{array}{c}0.14 \\
(0.50)\end{array}$ \\
\hline Collaborative $\times$ Teamwork & & & $\begin{array}{c}0.097^{*} \\
(2.01)\end{array}$ & $\begin{array}{l}0.073 \\
(1.26)\end{array}$ & $\begin{array}{c}0.095^{+} \\
(1.95)\end{array}$ & $\begin{array}{l}0.079 \\
(1.34)\end{array}$ \\
\hline Teamwork $\times$ Contract & & & & & $\begin{array}{l}0.21^{*} \\
(2.20)\end{array}$ & $\begin{array}{l}0.093 \\
(0.84)\end{array}$ \\
\hline Collaborative $\times$ Teamwork $\times$ Contract & & & & & $\begin{array}{l}0.059 \\
(0.22)\end{array}$ & $\begin{array}{l}-0.17 \\
(0.54)\end{array}$ \\
\hline Log of Number Employees & $\begin{array}{c}-0.027^{* *} \\
(3.15)\end{array}$ & $\begin{array}{c}-0.037^{* * *} \\
(3.43)\end{array}$ & $\begin{array}{c}-0.027^{* *} \\
(3.15)\end{array}$ & $\begin{array}{c}-0.037^{* * *} \\
(3.43)\end{array}$ & $\begin{array}{c}-0.028^{* *} \\
(3.19)\end{array}$ & $\begin{array}{c}-0.037^{* * *} \\
(3.44)\end{array}$ \\
\hline Log of Number Reviews & $\begin{array}{c}0.056^{* * *} \\
(3.45)\end{array}$ & $\begin{array}{c}0.059^{* *} \\
(3.12)\end{array}$ & $\begin{array}{c}0.056^{* * *} \\
(3.47)\end{array}$ & $\begin{array}{c}0.059^{* *} \\
(3.13)\end{array}$ & $\begin{array}{c}0.056^{* * *} \\
(3.49)\end{array}$ & $\begin{array}{c}0.059^{* *} \\
(3.13)\end{array}$ \\
\hline High Teamwork Occ. & $\begin{array}{c}-0.087^{* * *} \\
(3.67)\end{array}$ & $\begin{array}{c}-0.10^{* * *} \\
(3.85)\end{array}$ & $\begin{array}{c}-0.100^{* * *} \\
(4.02)\end{array}$ & $\begin{array}{c}-0.11^{* * *} \\
(3.97)\end{array}$ & $\begin{array}{c}-0.11^{* * *} \\
(4.30)\end{array}$ & $\begin{array}{c}-0.12^{* * *} \\
(4.06)\end{array}$ \\
\hline Unstructured Occ. & $\begin{array}{c}0.089^{* * *} \\
(4.73)\end{array}$ & $\begin{array}{c}0.091^{* * *} \\
(3.71)\end{array}$ & $\begin{array}{c}0.089^{* * *} \\
(4.73)\end{array}$ & $\begin{array}{c}0.091^{* * *} \\
(3.71)\end{array}$ & $\begin{array}{c}0.089^{* * *} \\
(4.73)\end{array}$ & $\begin{array}{c}0.091^{* * *} \\
(3.71)\end{array}$ \\
\hline High Coordination Occ. & $\begin{array}{c}0.014 \\
(0.58)\end{array}$ & $\begin{array}{l}-0.019 \\
(0.66)\end{array}$ & $\begin{array}{c}0.015 \\
(0.62)\end{array}$ & $\begin{array}{c}-0.018 \\
(0.64)\end{array}$ & $\begin{array}{l}0.015 \\
(0.64)\end{array}$ & $\begin{array}{c}-0.018 \\
(0.63)\end{array}$ \\
\hline Technical Skills & $\begin{array}{l}0.013 \\
(0.64)\end{array}$ & $\begin{array}{c}0.0098 \\
(0.38)\end{array}$ & $\begin{array}{l}0.013 \\
(0.62)\end{array}$ & $\begin{array}{c}0.0094 \\
(0.36)\end{array}$ & $\begin{array}{l}0.014 \\
(0.69)\end{array}$ & $\begin{array}{c}0.0100 \\
(0.38)\end{array}$ \\
\hline Cognitive Skills & $\begin{array}{l}-0.044 \\
(1.41)\end{array}$ & $\begin{array}{c}-0.0014 \\
(0.04)\end{array}$ & $\begin{array}{l}-0.044 \\
(1.41)\end{array}$ & $\begin{array}{c}-0.0014 \\
(0.03)\end{array}$ & $\begin{array}{l}-0.044 \\
(1.43)\end{array}$ & $\begin{array}{c}-0.0016 \\
(0.04)\end{array}$ \\
\hline Social Skills & $\begin{array}{l}0.032 \\
(1.35)\end{array}$ & $\begin{array}{l}0.033 \\
(1.06)\end{array}$ & $\begin{array}{l}0.032 \\
(1.35)\end{array}$ & $\begin{array}{l}0.033 \\
(1.06)\end{array}$ & $\begin{array}{l}0.033 \\
(1.38)\end{array}$ & $\begin{array}{l}0.033 \\
(1.07)\end{array}$ \\
\hline Manual Skills & $\begin{array}{c}-0.038^{*} \\
(2.30)\end{array}$ & $\begin{array}{l}-0.029 \\
(1.33)\end{array}$ & $\begin{array}{c}-0.038^{*} \\
(2.29)\end{array}$ & $\begin{array}{l}-0.029 \\
(1.32)\end{array}$ & $\begin{array}{c}-0.037^{*} \\
(2.25)\end{array}$ & $\begin{array}{l}-0.029 \\
(1.31)\end{array}$ \\
\hline Contract $\times$ Technical Skills & $\begin{array}{l}-0.024 \\
(0.64)\end{array}$ & $\begin{array}{c}-0.034 \\
(0.76)\end{array}$ & $\begin{array}{l}-0.024 \\
(0.64)\end{array}$ & $\begin{array}{l}-0.034 \\
(0.76)\end{array}$ & $\begin{array}{l}-0.049 \\
(1.37)\end{array}$ & $\begin{array}{r}-0.042 \\
(0.96)\end{array}$ \\
\hline Constant & $\begin{array}{l}0.60^{* *} \\
(2.68)\end{array}$ & $\begin{array}{c}1.59^{* * *} \\
(6.12)\end{array}$ & $\begin{array}{l}0.61^{* *} \\
(2.72)\end{array}$ & $\begin{array}{c}1.60^{* * *} \\
(6.15)\end{array}$ & $\begin{array}{l}0.62^{* *} \\
(2.77) \\
\end{array}$ & $\begin{array}{c}1.60^{* * *} \\
(6.17)\end{array}$ \\
\hline $\mathrm{N}$ & 57562 & 47157 & 57562 & 47157 & 57562 & 47157 \\
\hline
\end{tabular}

Notes. Absolute $t$ statistics are in parentheses. All models include all individual controls, as well as major occupation, industry, and year fixed effects. Standard errors are clustered by organization.

$+p<0.10,{ }^{*} p<0.05,{ }^{* *} p<0.01,{ }^{* * *} p<0.001$ 
Table 6: OLS Models Predicting Cultural Integration by Contracting, Hierarchical Norms, and Teamwork

\begin{tabular}{|c|c|c|c|c|c|c|}
\hline & $\begin{array}{c}(1) \\
\text { Overall }\end{array}$ & $\begin{array}{c}(2) \\
\text { Culture }\end{array}$ & $\begin{array}{c}(3) \\
\text { Overall }\end{array}$ & $\begin{array}{c}(4) \\
\text { Culture }\end{array}$ & $\begin{array}{c}(5) \\
\text { Overall }\end{array}$ & $\begin{array}{c}(6) \\
\text { Culture }\end{array}$ \\
\hline Contract & $\begin{array}{l}0.15^{* *} \\
(2.88)\end{array}$ & $\begin{array}{l}0.094 \\
(1.55)\end{array}$ & $\begin{array}{l}0.12^{*} \\
(2.10)\end{array}$ & $\begin{array}{l}0.059 \\
(0.94)\end{array}$ & $\begin{array}{l}-0.059 \\
(0.74)\end{array}$ & $\begin{array}{l}-0.056 \\
(0.62)\end{array}$ \\
\hline Hierarchical Norms & $\begin{array}{c}-0.24^{* * *} \\
(11.33)\end{array}$ & $\begin{array}{c}-0.29^{* * *} \\
(10.80)\end{array}$ & $\begin{array}{c}-0.25^{* * *} \\
(11.45)\end{array}$ & $\begin{array}{c}-0.29^{* * *} \\
(10.90)\end{array}$ & $\begin{array}{c}-0.22^{* * *} \\
(6.45)\end{array}$ & $\begin{array}{c}-0.26^{* * *} \\
(5.23)\end{array}$ \\
\hline Collaborative Norms & $\begin{array}{l}0.035 \\
(0.75)\end{array}$ & $\begin{array}{c}0.088 \\
(1.59)\end{array}$ & $\begin{array}{l}0.034 \\
(0.73)\end{array}$ & $\begin{array}{l}0.087 \\
(1.57)\end{array}$ & $\begin{array}{l}0.028 \\
(0.60)\end{array}$ & $\begin{array}{l}0.080 \\
(1.42)\end{array}$ \\
\hline Collaborative $\times$ Teamwork & $\begin{array}{l}0.096^{*} \\
(1.99)\end{array}$ & $\begin{array}{l}0.072 \\
(1.25)\end{array}$ & $\begin{array}{l}0.097^{*} \\
(2.02)\end{array}$ & $\begin{array}{l}0.073 \\
(1.27)\end{array}$ & $\begin{array}{l}0.10^{*} \\
(2.14)\end{array}$ & $\begin{array}{l}0.081 \\
(1.40)\end{array}$ \\
\hline Contract $\times$ Hierarchical & & & $\begin{array}{l}0.21^{*} \\
(2.20)\end{array}$ & $\begin{array}{l}0.24^{+} \\
(1.77)\end{array}$ & $\begin{array}{c}0.64^{* * *} \\
(3.97)\end{array}$ & $\begin{array}{c}0.86^{* * *} \\
(4.12)\end{array}$ \\
\hline Contract $\times$ Teamwork & & & & & $\begin{array}{c}0.32^{* * *} \\
(3.56)\end{array}$ & $\begin{array}{l}0.21^{*} \\
(1.99)\end{array}$ \\
\hline Hierarchical $\times$ Teamwork & & & & & $\begin{array}{r}-0.028 \\
(0.84)\end{array}$ & $\begin{array}{c}-0.040 \\
(0.82)\end{array}$ \\
\hline Contract $\times$ Hierarchical $\times$ Teamwork & & & & & $\begin{array}{c}-0.68^{* * *} \\
(3.33)\end{array}$ & $\begin{array}{c}-0.99^{* * *} \\
(3.68)\end{array}$ \\
\hline Log of Number Employees & $\begin{array}{c}-0.027^{* *} \\
(3.14)\end{array}$ & $\begin{array}{c}-0.037^{* * *} \\
(3.43)\end{array}$ & $\begin{array}{c}-0.027^{* *} \\
(3.14)\end{array}$ & $\begin{array}{c}-0.037^{* * *} \\
(3.43)\end{array}$ & $\begin{array}{c}-0.028^{* *} \\
(3.19)\end{array}$ & $\begin{array}{c}-0.037^{* * *} \\
(3.43)\end{array}$ \\
\hline Log of Number Reviews & $\begin{array}{c}0.056^{* * *} \\
(3.47)\end{array}$ & $\begin{array}{c}0.059^{* *} \\
(3.13)\end{array}$ & $\begin{array}{c}0.056^{* * *} \\
(3.47)\end{array}$ & $\begin{array}{c}0.059^{* *} \\
(3.12)\end{array}$ & $\begin{array}{c}0.056^{* * *} \\
(3.48)\end{array}$ & $\begin{array}{c}0.059^{* *} \\
(3.11)\end{array}$ \\
\hline High Teamwork Occ. & $\begin{array}{c}-0.099^{* * *} \\
(4.01)\end{array}$ & $\begin{array}{c}-0.11^{* * *} \\
(3.96)\end{array}$ & $\begin{array}{c}-0.099^{* * *} \\
(4.01)\end{array}$ & $\begin{array}{c}-0.11^{* * *} \\
(3.96)\end{array}$ & $\begin{array}{c}-0.10^{* * *} \\
(3.86)\end{array}$ & $\begin{array}{c}-0.11^{* * *} \\
(3.66)\end{array}$ \\
\hline Unstructured Occ. & $\begin{array}{c}0.089^{* * *} \\
(4.73)\end{array}$ & $\begin{array}{c}0.091^{* * *} \\
(3.71)\end{array}$ & $\begin{array}{c}0.089^{* * *} \\
(4.75)\end{array}$ & $\begin{array}{c}0.091^{* * * *} \\
(3.72)\end{array}$ & $\begin{array}{c}0.089^{* * *} \\
(4.76)\end{array}$ & $\begin{array}{c}0.092^{* * *} \\
(3.75)\end{array}$ \\
\hline High Coordination Occ. & $\begin{array}{l}0.015 \\
(0.62)\end{array}$ & $\begin{array}{r}-0.018 \\
(0.64)\end{array}$ & $\begin{array}{c}0.015 \\
(0.62)\end{array}$ & $\begin{array}{c}-0.018 \\
(0.64)\end{array}$ & $\begin{array}{l}0.016 \\
(0.65)\end{array}$ & $\begin{array}{l}-0.018 \\
(0.63)\end{array}$ \\
\hline Technical Skills & $\begin{array}{l}0.012 \\
(0.62)\end{array}$ & $\begin{array}{c}0.0094 \\
(0.36)\end{array}$ & $\begin{array}{l}0.013 \\
(0.65)\end{array}$ & $\begin{array}{c}0.0100 \\
(0.38)\end{array}$ & $\begin{array}{l}0.014 \\
(0.70)\end{array}$ & $\begin{array}{l}0.010 \\
(0.40)\end{array}$ \\
\hline Cognitive Skills & $\begin{array}{l}-0.044 \\
(1.41)\end{array}$ & $\begin{array}{c}-0.0013 \\
(0.03)\end{array}$ & $\begin{array}{l}-0.044 \\
(1.43)\end{array}$ & $\begin{array}{c}-0.0022 \\
(0.06)\end{array}$ & $\begin{array}{l}-0.045 \\
(1.46)\end{array}$ & $\begin{array}{c}-0.0026 \\
(0.07)\end{array}$ \\
\hline Social Skills & $\begin{array}{c}0.032 \\
(1.34)\end{array}$ & $\begin{array}{l}0.033 \\
(1.06)\end{array}$ & $\begin{array}{l}0.032 \\
(1.34)\end{array}$ & $\begin{array}{l}0.033 \\
(1.05)\end{array}$ & $\begin{array}{c}0.032 \\
(1.38)\end{array}$ & $\begin{array}{l}0.033 \\
(1.05)\end{array}$ \\
\hline Manual Skills & $\begin{array}{c}-0.038^{*} \\
(2.30)\end{array}$ & $\begin{array}{l}-0.029 \\
(1.33)\end{array}$ & $\begin{array}{c}-0.038^{*} \\
(2.29)\end{array}$ & $\begin{array}{l}-0.029 \\
(1.33)\end{array}$ & $\begin{array}{c}-0.038^{*} \\
(2.30)\end{array}$ & $\begin{array}{l}-0.030 \\
(1.35)\end{array}$ \\
\hline Contract $\times$ Technical Skills & $\begin{array}{l}-0.023 \\
(0.62)\end{array}$ & $\begin{array}{l}-0.034 \\
(0.75)\end{array}$ & $\begin{array}{l}-0.027 \\
(0.74)\end{array}$ & $\begin{array}{l}-0.035 \\
(0.79)\end{array}$ & $\begin{array}{l}-0.053 \\
(1.53)\end{array}$ & $\begin{array}{l}-0.049 \\
(1.17)\end{array}$ \\
\hline Constant & $\begin{array}{l}0.61^{* *} \\
(2.72)\end{array}$ & $\begin{array}{c}1.60^{* * *} \\
(6.15)\end{array}$ & $\begin{array}{l}0.61^{* *} \\
(2.73)\end{array}$ & $\begin{array}{c}1.60^{* * *} \\
(6.17)\end{array}$ & $\begin{array}{l}0.63^{* *} \\
(2.81)\end{array}$ & $\begin{array}{c}1.61^{* * *} \\
(6.20)\end{array}$ \\
\hline $\mathrm{N}$ & 57562 & 47157 & 57562 & 47157 & 57562 & 47157 \\
\hline
\end{tabular}

Notes. Absolute $t$ statistics are in parentheses. All models include all individual controls, as well as major occupation, industry, and year fixed effects. Standard errors are clustered by organization.

$+p<0.10,{ }^{*} p<0.05,{ }^{* *} p<0.01,{ }^{* * *} p<0.001$ 


\section{Appendix A}

Table A1: Cultural Integration Models with Additional Controls

\begin{tabular}{|c|c|c|c|c|c|c|c|c|}
\hline & $\begin{array}{c}\text { (T3.3) } \\
\text { Overall }\end{array}$ & $\begin{array}{c}\text { (T3.4) } \\
\text { Culture }\end{array}$ & $\begin{array}{c}\mathrm{T} 4.5) \\
\text { Overall }\end{array}$ & $\begin{array}{c}\text { (T4.6) } \\
\text { Culture }\end{array}$ & $\begin{array}{c}\mathrm{T} 5.5) \\
\text { Overall }\end{array}$ & $\begin{array}{c}\text { (T5.6) } \\
\text { Culture }\end{array}$ & $\begin{array}{c}\text { T6.5) } \\
\text { Overall }\end{array}$ & $\begin{array}{l}\text { (T6.6) } \\
\text { Culture }\end{array}$ \\
\hline Contractor & $\begin{array}{l}0.13^{*} \\
(2.10)\end{array}$ & $\begin{array}{c}0.11 \\
(1.46)\end{array}$ & $\begin{array}{c}0.014 \\
(0.14)\end{array}$ & $\begin{array}{c}0.18 \\
(1.41)\end{array}$ & $\begin{array}{l}0.073 \\
(0.69)\end{array}$ & $\begin{array}{c}0.18 \\
(1.41)\end{array}$ & $\begin{array}{c}-0.033 \\
(0.32)\end{array}$ & $\begin{array}{l}0.082 \\
(0.66)\end{array}$ \\
\hline Current Job & $\begin{array}{c}0.57^{* * *} \\
(34.90)\end{array}$ & $\begin{array}{c}0.60^{* * *} \\
(33.74)\end{array}$ & $\begin{array}{c}0.58^{* * *} \\
(32.87)\end{array}$ & $\begin{array}{c}0.60^{* * *} \\
(31.73)\end{array}$ & $\begin{array}{c}0.58^{* * *} \\
(32.97)\end{array}$ & $\begin{array}{c}0.60^{* * *} \\
(31.93)\end{array}$ & $\begin{array}{c}0.58^{* * *} \\
(32.94)\end{array}$ & $\begin{array}{c}0.60^{* * *} \\
(31.89)\end{array}$ \\
\hline Contract $\times$ Current Job & $\begin{array}{c}-0.12^{+} \\
(1.83)\end{array}$ & $\begin{array}{c}-0.24^{* *} \\
(2.83)\end{array}$ & $\begin{array}{c}-0.092 \\
(1.11)\end{array}$ & $\begin{array}{c}-0.28^{* *} \\
(2.78)\end{array}$ & $\begin{array}{l}-0.12 \\
(1.40)\end{array}$ & $\begin{array}{c}-0.30^{* *} \\
(2.96)\end{array}$ & $\begin{array}{l}-0.10 \\
(1.25)\end{array}$ & $\begin{array}{c}-0.28^{* *} \\
(2.84)\end{array}$ \\
\hline$\%$ Workers w Text Reviews & $\begin{array}{l}0.54^{+} \\
(1.92)\end{array}$ & $\begin{array}{c}0.39 \\
(1.09)\end{array}$ & $\begin{array}{c}0.36 \\
(1.18)\end{array}$ & $\begin{array}{c}0.27 \\
(0.68)\end{array}$ & $\begin{array}{l}0.59^{*} \\
(2.13)\end{array}$ & $\begin{array}{c}0.55 \\
(1.49)\end{array}$ & $\begin{array}{l}0.59^{*} \\
(2.13)\end{array}$ & $\begin{array}{c}0.55 \\
(1.50)\end{array}$ \\
\hline Norm Strength & $\begin{array}{c}0.035^{*} \\
(2.00)\end{array}$ & $\begin{array}{c}0.11^{* * *} \\
(4.78)\end{array}$ & $\begin{array}{r}-0.015 \\
(0.56)\end{array}$ & $\begin{array}{l}0.026 \\
(0.71)\end{array}$ & $\begin{array}{l}0.021 \\
(1.14)\end{array}$ & $\begin{array}{c}0.090^{* * *} \\
(3.78)\end{array}$ & $\begin{array}{c}0.022 \\
(1.18)\end{array}$ & $\begin{array}{c}0.090^{* * *} \\
(3.80)\end{array}$ \\
\hline Collaborative Norms & & & & & $\begin{array}{l}0.035 \\
(0.73)\end{array}$ & $\begin{array}{c}0.078 \\
(1.34)\end{array}$ & $\begin{array}{c}0.12^{* * *} \\
(4.56)\end{array}$ & $\begin{array}{c}0.14^{* * *} \\
(4.74)\end{array}$ \\
\hline Hierarchical Norms & & & & & $\begin{array}{c}-0.25^{* * *} \\
(11.49)\end{array}$ & $\begin{array}{c}-0.30^{* * * *} \\
(11.11)\end{array}$ & $\begin{array}{c}-0.23^{* * *} \\
(6.73)\end{array}$ & $\begin{array}{c}-0.27^{* * *} \\
(5.55)\end{array}$ \\
\hline High Teamwork Occ. & & & $\begin{array}{c}-0.091^{* * *} \\
(3.57)\end{array}$ & $\begin{array}{c}-0.092^{* *} \\
(2.95)\end{array}$ & $\begin{array}{c}-0.11^{* * *} \\
(4.47)\end{array}$ & $\begin{array}{c}-0.12^{* * *} \\
(4.30)\end{array}$ & $\begin{array}{c}-0.093^{* * *} \\
(3.68)\end{array}$ & $\begin{array}{c}-0.11^{* * *} \\
(3.74)\end{array}$ \\
\hline Contract $\times$ Strength & $\begin{array}{c}-0.13^{* *} \\
(2.60)\end{array}$ & $\begin{array}{c}-0.13^{*} \\
(2.41)\end{array}$ & $\begin{array}{c}-0.29^{* * *} \\
(3.53)\end{array}$ & $\begin{array}{c}-0.20^{*} \\
(2.00)\end{array}$ & $\begin{array}{c}-0.14^{*} \\
(2.12)\end{array}$ & $\begin{array}{c}-0.16^{*} \\
(2.28)\end{array}$ & $\begin{array}{c}-0.14^{*} \\
(2.23)\end{array}$ & $\begin{array}{c}-0.15^{*} \\
(2.28)\end{array}$ \\
\hline Contract $\times$ Teamwork & & & $\begin{array}{c}0.32^{* * *} \\
(3.36)\end{array}$ & $\begin{array}{c}0.12 \\
(1.00)\end{array}$ & $\begin{array}{l}0.20^{*} \\
(2.21)\end{array}$ & $\begin{array}{l}0.082 \\
(0.75)\end{array}$ & $\begin{array}{c}0.32^{* * *} \\
(3.57)\end{array}$ & $\begin{array}{l}0.20^{+} \\
(1.91)\end{array}$ \\
\hline Teamwork $\times$ Strength & & & $\begin{array}{l}0.034 \\
(1.42)\end{array}$ & $\begin{array}{c}0.066^{*} \\
(2.03)\end{array}$ & & & & \\
\hline Contract $\times$ Teamwork $\times$ Strength & & & $\begin{array}{l}0.26^{*} \\
(2.43)\end{array}$ & $\begin{array}{c}0.11 \\
(0.81)\end{array}$ & & & & \\
\hline Contract $\times$ Collaborative & & & & & $\begin{array}{c}0.0057 \\
(0.02)\end{array}$ & $\begin{array}{c}0.17 \\
(0.64)\end{array}$ & & \\
\hline Collaborative $\times$ Teamwork & & & & & $\begin{array}{c}0.094^{+} \\
(1.93)\end{array}$ & $\begin{array}{l}0.077 \\
(1.31)\end{array}$ & & \\
\hline Contract $\times$ Collaborative $\times$ Teamwork & & & & & $\begin{array}{l}0.083 \\
(0.31)\end{array}$ & $\begin{array}{l}-0.14 \\
(0.47)\end{array}$ & & \\
\hline Contract $\times$ Hierarchical & & & & & & & $\begin{array}{c}0.64^{* * *} \\
(4.05)\end{array}$ & $\begin{array}{c}0.84^{* * *} \\
(4.22)\end{array}$ \\
\hline Hierarchical $\times$ Teamwork & & & & & & & $\begin{array}{c}-0.023 \\
(0.69)\end{array}$ & $\begin{array}{r}-0.036 \\
(0.73)\end{array}$ \\
\hline Contract $\times$ Hierarchical $\times$ Teamwork & & & & & & & $\begin{array}{c}-0.64^{* *} \\
(3.11)\end{array}$ & $\begin{array}{c}-0.96^{* * *} \\
(3.63)\end{array}$ \\
\hline Constant & $\begin{array}{c}0.19 \\
(0.69) \\
\end{array}$ & $\begin{array}{c}1.24^{* * *} \\
(3.95) \\
\end{array}$ & $\begin{array}{c}0.26 \\
(1.15) \\
\end{array}$ & $\begin{array}{c}1.16^{* * *} \\
(4.36)\end{array}$ & $\begin{array}{l}0.51^{*} \\
(2.25)\end{array}$ & $\begin{array}{c}1.40^{* * *} \\
(5.33)\end{array}$ & $\begin{array}{l}0.51^{*} \\
(2.26)\end{array}$ & $\begin{array}{c}1.40^{* * *} \\
(5.33)\end{array}$ \\
\hline $\mathrm{N}$ & 68602 & 55715 & 57562 & 47157 & 57562 & 47157 & 57562 & 47157 \\
\hline
\end{tabular}

Notes. Each model is an alternate specification of a model in Tables 3-6: TX.Y refers to Table X, Model Y. Absolute $t$ statistics are in parentheses. All models include all individual controls, as well as occupation, industry, and year fixed effects. Standard errors are clustered by organization.

${ }^{+} p<0.10,{ }^{*} p<0.05,{ }^{* *} p<0.01,{ }^{* * *} p<0.001$ 
Table A2: Cultural Integration Models with Culture Measures Averaged Over All Years

\begin{tabular}{|c|c|c|c|c|c|c|c|c|}
\hline & $\begin{array}{l}\text { (T3.3) } \\
\text { Overall }\end{array}$ & $\begin{array}{l}\text { (T3.4) } \\
\text { Culture }\end{array}$ & $\begin{array}{c}\text { (T4.5) } \\
\text { Overall }\end{array}$ & $\begin{array}{l}\text { (T4.6) } \\
\text { Culture }\end{array}$ & $\begin{array}{l}\text { (T5.5) } \\
\text { Overall }\end{array}$ & $\begin{array}{l}\text { (T5.6) } \\
\text { Culture }\end{array}$ & $\begin{array}{l}\text { (T6.5) } \\
\text { Overall }\end{array}$ & $\begin{array}{l}\text { (T6.6) } \\
\text { Culture }\end{array}$ \\
\hline Contractor & $\begin{array}{l}0.063 \\
(1.62)\end{array}$ & $\begin{array}{r}-0.021 \\
(0.49)\end{array}$ & $\begin{array}{c}-0.018 \\
(0.25)\end{array}$ & $\begin{array}{l}0.013 \\
(0.15)\end{array}$ & $\begin{array}{c}-0.041 \\
(0.48)\end{array}$ & $\begin{array}{c}-0.012 \\
(0.11)\end{array}$ & $\begin{array}{c}-0.13 \\
(1.45)\end{array}$ & $\begin{array}{c}-0.14 \\
(1.39)\end{array}$ \\
\hline Norm Strength (mean) & $\begin{array}{c}0.072^{* *} \\
(3.19)\end{array}$ & $\begin{array}{c}0.14^{* * *} \\
(5.16)\end{array}$ & $\begin{array}{r}-0.019 \\
(0.53)\end{array}$ & $\begin{array}{l}0.047 \\
(1.08)\end{array}$ & $\begin{array}{c}0.049^{*} \\
(2.16)\end{array}$ & $\begin{array}{c}0.11^{* * *} \\
(3.91)\end{array}$ & $\begin{array}{c}0.049^{*} \\
(2.14)\end{array}$ & $\begin{array}{c}0.11^{* * *} \\
(3.90)\end{array}$ \\
\hline Collaborative Norms (mean) & & & & & $\begin{array}{c}0.076 \\
(1.19)\end{array}$ & $\begin{array}{l}0.17^{*} \\
(2.35)\end{array}$ & $\begin{array}{c}0.22^{* * *} \\
(5.74)\end{array}$ & $\begin{array}{c}0.27^{* * *} \\
(5.62)\end{array}$ \\
\hline Hierarchical Norms (mean) & & & & & $\begin{array}{c}-0.54^{* * *} \\
(13.15)\end{array}$ & $\begin{array}{c}-0.59^{* * *} \\
(11.81)\end{array}$ & $\begin{array}{c}-0.58^{* * *} \\
(9.46)\end{array}$ & $\begin{array}{c}-0.66^{* * *} \\
(8.89)\end{array}$ \\
\hline High Teamwork Occ. & & & $\begin{array}{c}-0.092^{* * *} \\
(3.64)\end{array}$ & $\begin{array}{c}-0.11^{* * *} \\
(3.73)\end{array}$ & $\begin{array}{c}-0.12^{* * *} \\
(4.61)\end{array}$ & $\begin{array}{c}-0.13^{* * *} \\
(4.19)\end{array}$ & $\begin{array}{c}-0.11^{* * *} \\
(3.52)\end{array}$ & $\begin{array}{c}-0.13^{* * *} \\
(3.92)\end{array}$ \\
\hline Contract $\times$ Strength & $\begin{array}{c}-0.19^{* *} \\
(3.18)\end{array}$ & $\begin{array}{c}-0.18^{* *} \\
(2.82)\end{array}$ & $\begin{array}{c}-0.35^{* * *} \\
(3.40)\end{array}$ & $\begin{array}{c}-0.28^{*} \\
(2.18)\end{array}$ & $\begin{array}{c}-0.21^{* *} \\
(2.62)\end{array}$ & $\begin{array}{c}-0.18^{*} \\
(2.04)\end{array}$ & $\begin{array}{c}-0.20^{* *} \\
(2.65)\end{array}$ & $\begin{array}{l}-0.17^{*} \\
(2.07)\end{array}$ \\
\hline Contract $\times$ Teamwork & & & $\begin{array}{c}0.29^{* *} \\
(3.23)\end{array}$ & $\begin{array}{c}0.13 \\
(1.21)\end{array}$ & $\begin{array}{l}0.24^{*} \\
(2.47)\end{array}$ & $\begin{array}{c}0.11 \\
(0.96)\end{array}$ & $\begin{array}{c}0.43^{* * *} \\
(3.99)\end{array}$ & $\begin{array}{c}0.34^{* *} \\
(2.72)\end{array}$ \\
\hline Teamwork $\times$ Strength & & & $\begin{array}{c}0.068^{*} \\
(2.09)\end{array}$ & $\begin{array}{c}0.065^{+} \\
(1.66)\end{array}$ & & & & \\
\hline Contract $\times$ Teamwork $\times$ Strength & & & $\begin{array}{l}0.28^{*} \\
(2.12)\end{array}$ & $\begin{array}{c}0.20 \\
(1.28)\end{array}$ & & & & \\
\hline Contract $\times$ Collaborative & & & & & $\begin{array}{c}0.31 \\
(0.95)\end{array}$ & $\begin{array}{c}0.26 \\
(0.70)\end{array}$ & & \\
\hline Collaborative $\times$ Teamwork & & & & & $\begin{array}{l}0.17^{*} \\
(2.35)\end{array}$ & $\begin{array}{c}0.11 \\
(1.41)\end{array}$ & & \\
\hline Contract $\times$ Collaborative $\times$ Teamwork & & & & & $\begin{array}{l}-0.23 \\
(0.66)\end{array}$ & $\begin{array}{l}-0.29 \\
(0.71)\end{array}$ & & \\
\hline Contract $\times$ Hierarchical & & & & & & & $\begin{array}{l}0.56^{*} \\
(2.45)\end{array}$ & $\begin{array}{c}0.72^{* *} \\
(2.69)\end{array}$ \\
\hline Hierarchical $\times$ Teamwork & & & & & & & $\begin{array}{l}0.042 \\
(0.71)\end{array}$ & $\begin{array}{l}0.083 \\
(1.16)\end{array}$ \\
\hline Contract $\times$ Hierarchical $\times$ Teamwork & & & & & & & $\begin{array}{c}-0.84^{* *} \\
(2.95)\end{array}$ & $\begin{array}{c}-1.06^{* *} \\
(3.11)\end{array}$ \\
\hline Constant & $\begin{array}{c}0.25 \\
(0.93)\end{array}$ & $\begin{array}{c}1.30^{* * *} \\
(4.16) \\
\end{array}$ & $\begin{array}{c}0.29 \\
(1.28)\end{array}$ & $\begin{array}{c}1.21^{* * *} \\
(4.59)\end{array}$ & $\begin{array}{l}0.45^{*} \\
(2.07)\end{array}$ & $\begin{array}{c}1.37^{* * *} \\
(5.23)\end{array}$ & $\begin{array}{l}0.44^{*} \\
(2.05)\end{array}$ & $\begin{array}{c}1.38^{* * *} \\
(5.25)\end{array}$ \\
\hline $\mathrm{N}$ & 68602 & 55715 & 57562 & 47157 & 57562 & 47157 & 57562 & 47157 \\
\hline
\end{tabular}

Notes. Each model is an alternate specification of a model in Tables 3-6: TX.Y refers to Table X, Model Y. Absolute $t$ statistics are in parentheses. All models include all individual controls, as well as occupation, industry, and year fixed effects. Standard errors are clustered by organization.

$+p<0.10,{ }^{*} p<0.05,{ }^{* *} p<0.01,{ }^{* * *} p<0.001$ 
Table A3: Cultural Integration Models with Alternate Strong Collaborative Norm Measure

\begin{tabular}{|c|c|c|c|c|c|c|}
\hline & $\begin{array}{l}(\mathrm{T} 5.1) \\
\text { Overall }\end{array}$ & $\begin{array}{l}\text { (T5.2) } \\
\text { Culture }\end{array}$ & $\begin{array}{c}(\mathrm{T} 5.3) \\
\text { Overall }\end{array}$ & $\begin{array}{c}\text { (T5.4) } \\
\text { Culture }\end{array}$ & $\begin{array}{l}(\mathrm{T} 5.5) \\
\text { Overall }\end{array}$ & $\begin{array}{c}\text { (T5.6) } \\
\text { Culture }\end{array}$ \\
\hline Contractor & $\begin{array}{l}0.11^{+} \\
(1.88)\end{array}$ & $\begin{array}{c}0.038 \\
(0.55)\end{array}$ & $\begin{array}{c}-0.0057 \\
(0.07)\end{array}$ & $\begin{array}{c}0.012 \\
(0.12)\end{array}$ & $\begin{array}{l}-0.015 \\
(0.18)\end{array}$ & $\begin{array}{c}-0.016 \\
(0.16)\end{array}$ \\
\hline Collaborative Norms (alt) & $\begin{array}{c}0.20^{* * *} \\
(8.35)\end{array}$ & $\begin{array}{c}0.26^{* * *} \\
(7.58)\end{array}$ & $\begin{array}{c}0.14^{* * *} \\
(3.51)\end{array}$ & $\begin{array}{c}0.23^{* * *} \\
(4.50)\end{array}$ & $\begin{array}{c}0.14^{* * *} \\
(3.40)\end{array}$ & $\begin{array}{c}0.22^{* * *} \\
(4.26)\end{array}$ \\
\hline Hierarchical Norms & $\begin{array}{c}-0.24^{* * *} \\
(11.11)\end{array}$ & $\begin{array}{c}-0.29^{* * *} \\
(10.69)\end{array}$ & $\begin{array}{c}-0.24^{* * *} \\
(11.12)\end{array}$ & $\begin{array}{c}-0.29^{* * *} \\
(10.70)\end{array}$ & $\begin{array}{c}-0.24^{* * *} \\
(11.12)\end{array}$ & $\begin{array}{c}-0.29^{* * *} \\
(10.70)\end{array}$ \\
\hline Norm Strength & $\begin{array}{c}0.021 \\
(1.13)\end{array}$ & $\begin{array}{c}0.090^{* * *} \\
(3.77)\end{array}$ & $\begin{array}{c}0.021 \\
(1.14)\end{array}$ & $\begin{array}{c}0.090^{* * *} \\
(3.78)\end{array}$ & $\begin{array}{c}0.021 \\
(1.14)\end{array}$ & $\begin{array}{c}0.090^{* * *} \\
(3.78)\end{array}$ \\
\hline High Autonomy Occ. & $\begin{array}{c}0.088^{* * *} \\
(4.72)\end{array}$ & $\begin{array}{c}0.089^{* * *} \\
(3.62)\end{array}$ & $\begin{array}{c}0.088^{* * *} \\
(4.75)\end{array}$ & $\begin{array}{c}0.089^{* * *} \\
(3.63)\end{array}$ & $\begin{array}{c}0.089^{* * *} \\
(4.75)\end{array}$ & $\begin{array}{c}0.089^{* * *} \\
(3.64)\end{array}$ \\
\hline High Teamwork Occ. & $\begin{array}{c}-0.086^{* * *} \\
(3.62)\end{array}$ & $\begin{array}{c}-0.11^{* * *} \\
(3.88)\end{array}$ & $\begin{array}{c}-0.10^{* * *} \\
(4.20)\end{array}$ & $\begin{array}{c}-0.11^{* * *} \\
(4.07)\end{array}$ & $\begin{array}{c}-0.11^{* * *} \\
(4.21)\end{array}$ & $\begin{array}{c}-0.12^{* * *} \\
(4.12)\end{array}$ \\
\hline High Coordination Occ. & $\begin{array}{l}0.014 \\
(0.57)\end{array}$ & $\begin{array}{r}-0.019 \\
(0.70)\end{array}$ & $\begin{array}{l}0.016 \\
(0.64)\end{array}$ & $\begin{array}{r}-0.019 \\
(0.67)\end{array}$ & $\begin{array}{l}0.016 \\
(0.64)\end{array}$ & $\begin{array}{c}-0.019 \\
(0.67)\end{array}$ \\
\hline Technical Skills & $\begin{array}{l}0.015 \\
(0.77)\end{array}$ & $\begin{array}{l}0.013 \\
(0.52)\end{array}$ & $\begin{array}{l}0.017 \\
(0.83)\end{array}$ & $\begin{array}{l}0.014 \\
(0.54)\end{array}$ & $\begin{array}{l}0.017 \\
(0.83)\end{array}$ & $\begin{array}{l}0.014 \\
(0.54)\end{array}$ \\
\hline Cognitive Skills & $\begin{array}{c}-0.049 \\
(1.59)\end{array}$ & $\begin{array}{c}-0.0097 \\
(0.24)\end{array}$ & $\begin{array}{c}-0.049 \\
(1.61)\end{array}$ & $\begin{array}{c}-0.0096 \\
(0.24)\end{array}$ & $\begin{array}{c}-0.049 \\
(1.61)\end{array}$ & $\begin{array}{c}-0.0095 \\
(0.24)\end{array}$ \\
\hline Social Skills & $\begin{array}{l}0.036 \\
(1.55)\end{array}$ & $\begin{array}{c}0.043 \\
(1.42)\end{array}$ & $\begin{array}{l}0.038 \\
(1.63)\end{array}$ & $\begin{array}{l}0.044 \\
(1.44)\end{array}$ & $\begin{array}{l}0.038 \\
(1.63)\end{array}$ & $\begin{array}{l}0.044 \\
(1.43)\end{array}$ \\
\hline Manual Skills & $\begin{array}{c}-0.037^{*} \\
(2.25)\end{array}$ & $\begin{array}{r}-0.026 \\
(1.20)\end{array}$ & $\begin{array}{c}-0.037^{*} \\
(2.25)\end{array}$ & $\begin{array}{l}-0.026 \\
(1.21)\end{array}$ & $\begin{array}{c}-0.037^{*} \\
(2.25)\end{array}$ & $\begin{array}{r}-0.026 \\
(1.21)\end{array}$ \\
\hline Log of Number Employees & $\begin{array}{c}-0.029^{* *} \\
(3.26)\end{array}$ & $\begin{array}{c}-0.028^{*} \\
(2.56)\end{array}$ & $\begin{array}{c}-0.029^{* *} \\
(3.28)\end{array}$ & $\begin{array}{c}-0.028^{*} \\
(2.55)\end{array}$ & $\begin{array}{c}-0.029^{* *} \\
(3.28)\end{array}$ & $\begin{array}{c}-0.028^{*} \\
(2.55)\end{array}$ \\
\hline Log of Number Reviews & $\begin{array}{c}0.063^{* * *} \\
(3.93)\end{array}$ & $\begin{array}{c}0.064^{* * *} \\
(3.38)\end{array}$ & $\begin{array}{c}0.063^{* * *} \\
(3.94)\end{array}$ & $\begin{array}{c}0.064^{* * *} \\
(3.37)\end{array}$ & $\begin{array}{c}0.063^{\text {*** }} \\
(3.94)\end{array}$ & $\begin{array}{c}0.064^{* * *} \\
(3.37)\end{array}$ \\
\hline Contract $\times$ Technical Skills & $\begin{array}{r}-0.027 \\
(0.75)\end{array}$ & $\begin{array}{r}-0.036 \\
(0.82)\end{array}$ & $\begin{array}{r}-0.054 \\
(1.55)\end{array}$ & $\begin{array}{c}-0.048 \\
(1.09)\end{array}$ & $\begin{array}{r}-0.055 \\
(1.57)\end{array}$ & $\begin{array}{l}-0.050 \\
(1.15)\end{array}$ \\
\hline Contract $\times$ Strength & $\begin{array}{l}-0.14^{*} \\
(2.03)\end{array}$ & $\begin{array}{c}-0.16^{*} \\
(2.27)\end{array}$ & $\begin{array}{c}-0.14^{*} \\
(2.21)\end{array}$ & $\begin{array}{l}-0.16^{*} \\
(2.35)\end{array}$ & $\begin{array}{l}-0.14^{*} \\
(2.20)\end{array}$ & $\begin{array}{l}-0.16^{*} \\
(2.34)\end{array}$ \\
\hline Contract $\times$ Collaborative & & & $\begin{array}{r}-0.020 \\
(0.18)\end{array}$ & $\begin{array}{l}-0.12 \\
(0.89)\end{array}$ & $\begin{array}{l}0.047 \\
(0.30)\end{array}$ & $\begin{array}{l}0.056 \\
(0.28)\end{array}$ \\
\hline Contract $\times$ Teamwork & & & $\begin{array}{c}0.22^{* *} \\
(2.59)\end{array}$ & $\begin{array}{l}0.079 \\
(0.77)\end{array}$ & $\begin{array}{l}0.24^{*} \\
(2.51)\end{array}$ & $\begin{array}{c}0.13 \\
(1.13)\end{array}$ \\
\hline Teamwork $\times$ Collaborative & & & $\begin{array}{c}0.076^{+} \\
(1.73)\end{array}$ & $\begin{array}{l}0.042 \\
(0.75)\end{array}$ & $\begin{array}{c}0.080^{+} \\
(1.78)\end{array}$ & $\begin{array}{l}0.054 \\
(0.94)\end{array}$ \\
\hline Contract $\times$ Collaborative $\times$ Teamwork & & & & & $\begin{array}{l}-0.12 \\
(0.56)\end{array}$ & $\begin{array}{l}-0.33 \\
(1.21)\end{array}$ \\
\hline Constant & $\begin{array}{l}0.54^{*} \\
(2.42)\end{array}$ & $\begin{array}{c}1.43^{* * *} \\
(5.56) \\
\end{array}$ & $\begin{array}{l}0.55^{*} \\
(2.50)\end{array}$ & $\begin{array}{c}1.44^{* * *} \\
(5.60) \\
\end{array}$ & $\begin{array}{l}0.55^{*} \\
(2.50)\end{array}$ & $\begin{array}{c}1.44^{* * *} \\
(5.60) \\
\end{array}$ \\
\hline $\mathrm{N}$ & 57562 & 47157 & 57562 & 47157 & 57562 & 47157 \\
\hline
\end{tabular}

Notes. Each model is an alternate specification of a model in Table 5: T5.Y refers to Table 5, Model Y. Absolute $t$ statistics are in parentheses. All models include all individual controls, as well as occupation, industry, and year fixed effects. Standard errors are clustered by organization.

$+p<0.10,{ }^{*} p<0.05,{ }^{* *} p<0.01,{ }^{* * *} p<0.001$ 
Table A4: Cultural Integration Models Excluding Management Occupations

\begin{tabular}{|c|c|c|c|c|c|c|c|c|}
\hline & $\begin{array}{l}\text { (T3.3) } \\
\text { Overall }\end{array}$ & $\begin{array}{l}\text { (T3.4) } \\
\text { Culture }\end{array}$ & $\begin{array}{l}\mathrm{T} 4.5) \\
\text { Overall }\end{array}$ & $\begin{array}{l}\text { (T4.6) } \\
\text { Culture }\end{array}$ & $\begin{array}{l}\text { (T5.5) } \\
\text { Overall }\end{array}$ & $\begin{array}{l}\text { (T5.6) } \\
\text { Culture }\end{array}$ & $\begin{array}{l}\text { (T6.5) } \\
\text { Overall }\end{array}$ & $\begin{array}{l}\text { (T6.6) } \\
\text { Culture }\end{array}$ \\
\hline Contractor & $\begin{array}{l}0.049 \\
(1.15)\end{array}$ & $\begin{array}{r}-0.062 \\
(1.22)\end{array}$ & $\begin{array}{c}-0.046 \\
(0.62)\end{array}$ & $\begin{array}{l}-0.019 \\
(0.21)\end{array}$ & $\begin{array}{c}0.00074 \\
(0.01)\end{array}$ & $\begin{array}{c}-0.034 \\
(0.36)\end{array}$ & $\begin{array}{c}-0.100 \\
(1.26)\end{array}$ & $\begin{array}{l}-0.13 \\
(1.43)\end{array}$ \\
\hline Collaborative Norms & & & & & $\begin{array}{l}0.029 \\
(0.59)\end{array}$ & $\begin{array}{l}0.062 \\
(1.07)\end{array}$ & $\begin{array}{c}0.092^{* * *} \\
(3.35)\end{array}$ & $\begin{array}{l}0.11^{* *} \\
(3.09)\end{array}$ \\
\hline Hierarchical Norms & & & & & $\begin{array}{c}-0.23^{* * *} \\
(9.19)\end{array}$ & $\begin{array}{c}-0.27^{* * *} \\
(8.35)\end{array}$ & $\begin{array}{c}-0.22^{* * *} \\
(6.13)\end{array}$ & $\begin{array}{c}-0.28^{* * *} \\
(5.41)\end{array}$ \\
\hline Norm Strength & $\begin{array}{c}0.038^{+} \\
(1.86)\end{array}$ & $\begin{array}{c}0.098^{* * *} \\
(3.87)\end{array}$ & $\begin{array}{l}-0.019 \\
(0.69)\end{array}$ & $\begin{array}{c}-0.0019 \\
(0.05)\end{array}$ & $\begin{array}{c}0.0080 \\
(0.36)\end{array}$ & $\begin{array}{c}0.060^{*} \\
(2.12)\end{array}$ & $\begin{array}{c}0.0089 \\
(0.40)\end{array}$ & $\begin{array}{l}0.061^{*} \\
(2.14)\end{array}$ \\
\hline Contract $\times$ Strength & $\begin{array}{l}-0.11^{*} \\
(2.12)\end{array}$ & $\begin{array}{r}-0.13^{*} \\
(2.19)\end{array}$ & $\begin{array}{c}-0.26^{* * *} \\
(3.30)\end{array}$ & $\begin{array}{r}-0.19^{+} \\
(1.94)\end{array}$ & $\begin{array}{l}-0.10 \\
(1.50)\end{array}$ & $\begin{array}{l}-0.15^{*} \\
(2.12)\end{array}$ & $\begin{array}{l}-0.11 \\
(1.63)\end{array}$ & $\begin{array}{r}-0.15^{*} \\
(2.12)\end{array}$ \\
\hline High Teamwork Occ. & & & $\begin{array}{c}-0.061^{*} \\
(2.38)\end{array}$ & $\begin{array}{c}-0.061^{+} \\
(1.92)\end{array}$ & $\begin{array}{c}-0.080^{* *} \\
(3.24)\end{array}$ & $\begin{array}{c}-0.097^{* * *} \\
(3.36)\end{array}$ & $\begin{array}{c}-0.063^{*} \\
(2.45)\end{array}$ & $\begin{array}{c}-0.088^{* *} \\
(3.06)\end{array}$ \\
\hline Contract $\times$ Teamwork & & & $\begin{array}{c}0.32^{* *} \\
(3.26)\end{array}$ & $\begin{array}{l}0.081 \\
(0.67)\end{array}$ & $\begin{array}{l}0.19^{*} \\
(1.99)\end{array}$ & $\begin{array}{l}0.047 \\
(0.41)\end{array}$ & $\begin{array}{r}0.31^{* *} \\
(3.25)\end{array}$ & $\begin{array}{l}0.18^{+} \\
(1.65)\end{array}$ \\
\hline Teamwork $\times$ Strength & & & $\begin{array}{l}0.034 \\
(1.33)\end{array}$ & $\begin{array}{l}0.083^{*} \\
(2.38)\end{array}$ & & & & \\
\hline Contract $\times$ Teamwork $\times$ Strength & & & $\begin{array}{l}0.30^{* *} \\
(2.72)\end{array}$ & $\begin{array}{c}0.10 \\
(0.77)\end{array}$ & & & & \\
\hline Contract $\times$ Collaborative & & & & & $\begin{array}{l}0.013 \\
(0.06)\end{array}$ & $\begin{array}{c}0.20 \\
(0.72)\end{array}$ & & \\
\hline Collaborative $\times$ Teamwork & & & & & $\begin{array}{l}0.081 \\
(1.48)\end{array}$ & $\begin{array}{l}0.057 \\
(0.92)\end{array}$ & & \\
\hline Contract $\times$ Collaborative $\times$ Teamwork & & & & & $\begin{array}{l}0.082 \\
(0.30)\end{array}$ & $\begin{array}{l}-0.14 \\
(0.44)\end{array}$ & & \\
\hline Contract $\times$ Hierarchical & & & & & & & $\begin{array}{c}0.66^{* * *} \\
(4.11)\end{array}$ & $\begin{array}{c}0.92^{* * *} \\
(4.51)\end{array}$ \\
\hline Hierarchical $\times$ Teamwork & & & & & & & $\begin{array}{r}-0.028 \\
(0.75)\end{array}$ & $\begin{array}{c}-0.0078 \\
(0.15)\end{array}$ \\
\hline Contract $\times$ Hierarchical $\times$ Teamwork & & & & & & & $\begin{array}{c}-0.61^{* *} \\
(2.86)\end{array}$ & $\begin{array}{c}-1.03^{* * *} \\
(3.77)\end{array}$ \\
\hline Constant & $\begin{array}{c}0.12 \\
(0.28)\end{array}$ & $\begin{array}{c}1.34^{* * *} \\
(3.72)\end{array}$ & $\begin{array}{c}0.14 \\
(0.46)\end{array}$ & $\begin{array}{c}1.13^{* * *} \\
(3.44)\end{array}$ & $\begin{array}{c}0.34 \\
(1.13)\end{array}$ & $\begin{array}{c}1.32^{* * *} \\
(4.09)\end{array}$ & $\begin{array}{c}0.35 \\
(1.15)\end{array}$ & $\begin{array}{c}1.33^{* * *} \\
(4.13)\end{array}$ \\
\hline Other Controls & yes & yes & yes & yes & yes & yes & yes & yes \\
\hline Occupation FEs & yes & yes & yes & yes & yes & yes & yes & yes \\
\hline Industry FEs & yes & yes & yes & yes & yes & yes & yes & yes \\
\hline Year FEs & yes & yes & yes & yes & yes & yes & yes & yes \\
\hline $\mathrm{N}$ & 45128 & 36404 & 35682 & 29133 & 35682 & 29133 & 35682 & 29133 \\
\hline
\end{tabular}

Notes. Each model is an alternate specification of a model in Tables 3-6: TX.Y refers to Table X, Model Y. Absolute $t$ statistics are in parentheses. All models include all individual controls, as well as occupation, industry, and year fixed effects. Standard errors are clustered by organization.

${ }^{+} p<0.10,{ }^{*} p<0.05,{ }^{* *} p<0.01,{ }^{* * *} p<0.001$ 


\section{Appendix B}

\section{Detecting Cultural Topics Using Latent Dirichlet Allocation}

Constructing a measure of norm strength involves three steps: 1) training a topic model to identify a set of cultural topics across all reviews on the site, 2) fitting that model to reviews in the analytical sample to identify which cultural topics a worker is discussing in each review, and 3) measuring norm strength for each firm/period by calculating the similarity of cultural topics mentioned across workers.

A challenge in analyzing this type of free response text is identifying which content is germane to organizational culture. The goal is to identify the linguistic signatures of cultural norms that characterize work within an organization. For example, an organization may emphasize deliberateness, caution, and precision over speed, autonomy, and a willingness to make mistakes. Employees describing such an organization are expected to use words and phrases that describe and expound upon these normative conventions.

Many prior methods of measuring organizational culture require researchers to a priori define a general set of cultural dimensions that are purportedly inclusive of the cultures of many firms (O'Reilly et al., 1991). In contrast, this method uses an inductive approach to identify those topics that workers across all firms in the data collectively consider germane to organizational culture. The key assumption made is that when workers write about corporate culture, they sometimes explicitly use the word "culture" or a synonym, and sometimes do not. Regardless, the presence of a culture synonym is a label that indicates a given phrase contains content relevant to culture.

First, a training dataset is constructed of the nearly one million sentences or phrases that contain the word "culture" or a synonym across all reviews on the Glassdoor website ${ }^{6}$ Each phrase is treated as a vector of unigram counts, or a "bag of words," which assumes that topical content can be identified from word frequencies regardless of word order (Blei et al., 2003).

A Latent Dirichlet Allocation (LDA) topic model is then used to identify a set of cultural topics observed in the text. The intuition behind LDA is that it identifies clusters of words that tend to co-

\footnotetext{
${ }^{6}$ The synonyms are environment, atmosphere, attitude, climate, value, philosophy, and belief.
} 
occur in the same phrase across many different phrases, such that semantically meaningful cultural topics are identified based on the frequent co-occurrence of these word clusters. In accordance with Corritore et al. (2019), the LDA model is tuned to identify a set of 500 culture topics. Outputting a large number of topics ensures that conceptually meaningful distinctions between cultural topics are teased apart. ${ }^{7}$

Next, the trained LDA model is fit to reviews in the analytic sample to identify the cultural topics that workers discuss. Based on unigram counts, each review is assigned a topic probability distribution that denotes the distribution of the cultural topics mentioned in the review. Figure 8 is a stylized illustration of this process. The LDA model predicts that two reviews with similar topic probability distributions contain similar cultural content.

Lastly, the similarity of the cultural topics mentioned across workers for a given firm/period is assessed. Each review $i$ is represented as a probability distribution $p$ indicating the relative proportion of each cultural topic $c$ estimated as present in the review text. Norm strength for a given firm/period is defined as one minus the mean Jensen-Shannon (JS) divergence between the LDA probability distributions for all unordered pairs of reviews $i, j$ for that firm/period, formally:

$$
A=1-\frac{\sum_{i, j} J S\left(p_{i}, p_{j}\right)}{\sum_{i, j}}, \text { for all }\{i, j \mid i<j\}
$$

where the JS-divergence between the two probability distributions is defined as:

$$
J S\left(p_{i}, p_{j}\right)=\frac{1}{2} K L\left(p_{i}, M\right)+\frac{1}{2} K L\left(p_{j}, M\right)
$$

\footnotetext{
${ }^{7}$ Leading research on LDA models finds that, after some point, adding additional topics merely "nibbles away" at existing topics rather than fundamentally altering the topic distribution. Consequently, it is common practice to use more topics rather than fewer when identifying all relevant topics in a text corpus (Wallach et al., 2009, p. 8).
} 
and where $M=\frac{1}{2}\left(p_{i}+p_{j}\right)$ and $K L\left(p_{i}, M\right)$ is the Kullback-Leibler divergence of $M$ from $p_{i}$ :

$$
K L\left(p_{i}, M\right)=\sum_{c \in C} p_{i}(c) \log _{2} \frac{p_{i}(c)}{M(c)}
$$

JS-divergence is an entropy based measure that is particularly well-suited for measuring the distance between the sparse, power-law distributions that are typically observed in natural language processing (Corritore et al., 2019; Goldberg et al., 2016; Srivastava et al., 2017). The resulting norm strength measure is roughly normally distributed.

\section{Figure 8}

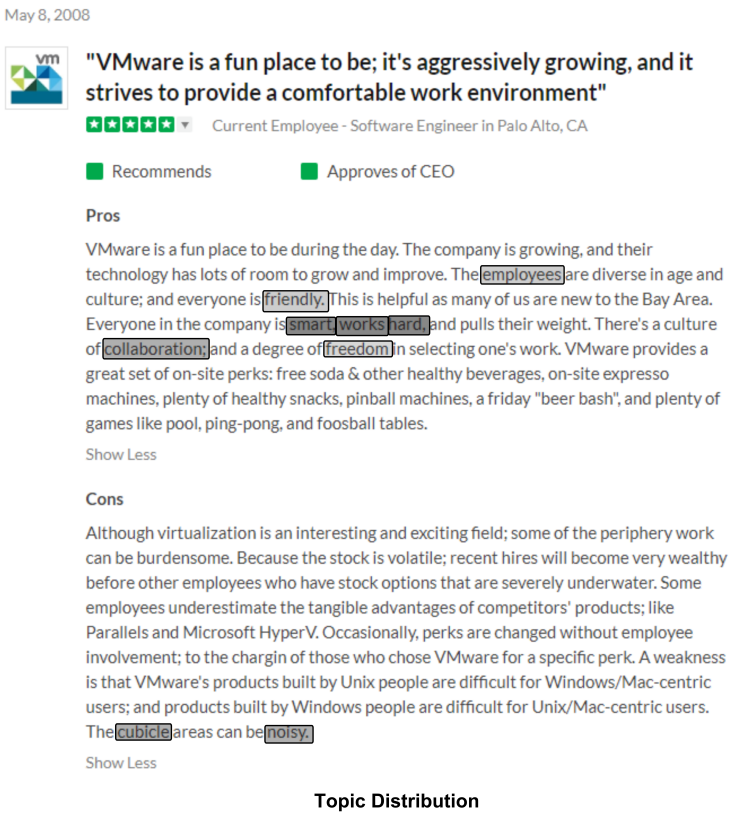




\section{Appendix C}

\section{Measuring Particular Types of Norms}

We identified organization/years with strong collaborative and hierarchical norms using a variant of the topic modeling approach. We adopt a 65 topic solution manually pruned by Corritore et al. (2019) to both remove difficult to interpret topics and combine seemingly redundant topics. The highest weighted words for each of the 65 topics are listed in Table C1.

Corritore et al. (2019) first began with a 100 topic model to make the task of manual coding more tractable. Second, they (the three co-authors) independently reviewed the top 25 word stems associated with each topic to determine: (1) which topics to drop because they seemed to lack coherence; (2) which topics to combine because they seemed redundant; and (3) what semantic label to assign to the remaining topics. Disagreements were reconciled by: (1) discarding topics that at least two coders identified as lacking coherence (20 topics were so identified); and (2) of the remaining 80 topics, combining topics when at least two coders had independently combined them. After coming to agreement about a handful of additional cases, this process left 65 topics. 
Table C1: 65 Culture Topics

\begin{tabular}{|c|c|c|}
\hline Topic \# & Label & Top 25 Words \\
\hline 49 & teamwork & $\begin{array}{l}\text { team member support orient collabor strong } \\
\text { manag work build spirit posit leadership player } \\
\text { leader encourag excel foster true promot execut } \\
\text { cohes mate cooper focus }\end{array}$ \\
\hline 41,80 & hierarchy & $\begin{array}{l}\text { manag level upper senior micro employe middl } \\
\text { staff support posit style entri understand execut } \\
\text { poor higher approach lower direct director touch } \\
\text { top care mid listen }\end{array}$ \\
\hline 38 & aggressive & $\begin{array}{l}\text { top compani line bank aggress corpor manag } \\
\text { bottom start firm invest notch employe privat } \\
\text { passiv financi industri front busi heavi public ac- } \\
\text { count gener client }\end{array}$ \\
\hline 11 & poor leadership & $\begin{array}{l}\text { lack manag leadership commun poor direct clear } \\
\text { senior vision plan strategi account execut lead } \\
\text { due depart process busi weak structur organ top } \\
\text { chaotic reactiv }\end{array}$ \\
\hline 71 & $\begin{array}{l}\text { hostile manage- } \\
\text { ment }\end{array}$ & $\begin{array}{l}\text { manag employe hostil unprofession abus favorit } \\
\text { hr behavior bulli bad horribl rude disrespect neg } \\
\text { treat staff lie harass supervisor practic uneth } \\
\text { toxic yell creat }\end{array}$ \\
\hline 84 & blame culture & $\begin{array}{l}\text { problem issu manag point blame review solv em- } \\
\text { ploye thing neg person fix address respons finger } \\
\text { wrong mistak pass real account hr find under- } \\
\text { stand deal }\end{array}$ \\
\hline 24,76 & work life balance & $\begin{array}{l}\text { work life balanc good healthi excel flexibl per- } \\
\text { son compens maintain brown perfect nose home } \\
\text { worklif emphasi sheet compens superb strike } \\
\text { conduc workahol memori emphas basic }\end{array}$ \\
\hline 51 & fair compensation & $\begin{array}{l}\text { good benefit pay decent great compens work } \\
\text { fair packag salari competit excel locat perk train } \\
\text { stabl offer cowork gener adequ fairli pto master } \\
\text { descent }\end{array}$ \\
\hline 58 & $\begin{array}{l}\text { competitive com- } \\
\text { pensation }\end{array}$ & $\begin{array}{l}\text { salari benefit competit pay averag compens } \\
\text { good industri compar low standard market lower } \\
\text { packag offer work fair similar competitor par } \\
\text { higher slightli area scale }\end{array}$ \\
\hline 78 & benefits & $\begin{array}{l}\text { benefit health great insur plan employe medic } \\
\text { pay vacat paid offer match excel packag gener } \\
\text { includ care time compens program stock bonu } \\
\text { reimburs retir }\end{array}$ \\
\hline 29 & bureaucracy & $\begin{array}{l}\text { make decis slow process thing risk difficult lot } \\
\text { made move busi red polit corpor tape bureau- } \\
\text { crat improv conserv bureaucraci progress impact } \\
\text { frustrat lead avers }\end{array}$ \\
\hline
\end{tabular}




\begin{tabular}{|c|c|c|}
\hline 3 & $\begin{array}{ll}\text { caring } & \text { environ- } \\
\text { ment } & \end{array}$ & $\begin{array}{l}\text { employe care treat manag famili staff compani } \\
\text { patient genuin hospit nurs health owner equal } \\
\text { number resid gener employ clinic children show } \\
\text { import understand treatment }\end{array}$ \\
\hline 20 & challenge & $\begin{array}{l}\text { difficult work time make challeng move thing } \\
\text { hard find tough deal person peopl adjust face } \\
\text { type bit quickli understand job adapt thrive } \\
\text { statu busi }\end{array}$ \\
\hline 22 & dynamism & $\begin{array}{l}\text { work challeng project interest client dynam ex- } \\
\text { cit lot stimul divers intellectu technic technolog } \\
\text { engag reward assign task team varieti involv in- } \\
\text { tern great collabor offer }\end{array}$ \\
\hline 91 & fast pace & $\begin{array}{l}\text { fast pace challeng grow dynam move excit slow } \\
\text { face learn quickli enjoy fun bore quick thrive de- } \\
\text { mand extrem day constantli adapt handl toe in- } \\
\text { tens }\end{array}$ \\
\hline 60 & community & $\begin{array}{l}\text { strong compani sens commun ethic employe } \\
\text { teamwork integr corpor leadership focu excel } \\
\text { safeti posit divers commit collabor promot pride } \\
\text { profession core emphasi organ famili }\end{array}$ \\
\hline 28 & performance & $\begin{array}{l}\text { perform base polit promot highli competit re- } \\
\text { ward review system driven recognit rank manag } \\
\text { intern merit compens top individu compet peer } \\
\text { talent result evalu process }\end{array}$ \\
\hline 79 & cut-throat & $\begin{array}{l}\text { cut technolog edg throat due cost constant layoff } \\
\text { busi lead econom compani budget year unstabl } \\
\text { competit creat recent frequent result continu re- } \\
\text { duc futur increas }\end{array}$ \\
\hline 15 & safety & $\begin{array}{l}\text { work control condit shop clean equip manag } \\
\text { safeti air plant hot physic dirti system build area } \\
\text { poor cold run qualiti floor manufactur mental } \\
\text { offic }\end{array}$ \\
\hline 33 & procedural & $\begin{array}{l}\text { corpor polici govern rule union contract employe } \\
\text { agenc due state standard oper employ time issu } \\
\text { strict contractor procedur polit regul public or- } \\
\text { gan militari ad }\end{array}$ \\
\hline 88 & creative & $\begin{array}{l}\text { creativ innov collabor encourag entrepreneuri } \\
\text { support foster freedom challeng idea highli dy- } \\
\text { nam motiv product independ talent individu in- } \\
\text { spir initi creat spirit teamwork design reward }\end{array}$ \\
\hline 75 & consultative & $\begin{array}{l}\text { busi firm client consult model market oper real } \\
\text { practic partner unit run success understand side } \\
\text { strong strategi focu develop area focus invest in- } \\
\text { dustri aspect }\end{array}$ \\
\hline
\end{tabular}




\begin{tabular}{|c|c|c|}
\hline 4 & customer focus & $\begin{array}{l}\text { custom servic product qualiti employe client fo- } \\
\text { cus focu compani base care deliv satisfact ex- } \\
\text { cel relationship experi improv result serv centric } \\
\text { happi sale interact creat }\end{array}$ \\
\hline 95 & brand focus & $\begin{array}{l}\text { compani industri product market brand strong } \\
\text { leader mobil innov great reput global world big } \\
\text { upward excit media lead competit interest digit } \\
\text { field financi stabl }\end{array}$ \\
\hline 35,19 & $\begin{array}{l}\text { learning } \quad \text { and } \\
\text { training }\end{array}$ & $\begin{array}{l}\text { experi train learn program skill support knowl- } \\
\text { edg resourc gain manag technic profession op- } \\
\text { portun develop lot excel improv intern set hu- } \\
\text { man abil mentor share job industri }\end{array}$ \\
\hline $54,56,21$ & $\begin{array}{l}\text { development and } \\
\text { growth }\end{array}$ & $\begin{array}{l}\text { career opportun profession advanc growth limit } \\
\text { room person develop lot learn progress great } \\
\text { grow path compani support skill potenti plenti } \\
\text { excel start move challeng promot }\end{array}$ \\
\hline 77 & growth oriented & $\begin{array}{l}\text { compani grow continu improv growth busi start } \\
\text { challeng maintain quickli pain rapidli constantli } \\
\text { startup evolv success move thing excit expand } \\
\text { organ small rapid process }\end{array}$ \\
\hline 72 & gender diversity & $\begin{array}{l}\text { divers boy women club group promot corpor } \\
\text { school cliqu domin male bit femal network type } \\
\text { mental age social men part conserv inclus polit } \\
\text { workplac }\end{array}$ \\
\hline 66 & engineering & $\begin{array}{l}\text { technolog develop product engin softwar system } \\
\text { design process tool project latest tech technic } \\
\text { agil date test innov comput market outdat prac- } \\
\text { tic learn data exposur }\end{array}$ \\
\hline 57 & team excellence & $\begin{array}{l}\text { great work excel team benefit support fan- } \\
\text { tast colleagu worker train outstand leadership } \\
\text { peer superb solid compens terrif enviro brilliant } \\
\text { teamwork postiv ambienc rough etho }\end{array}$ \\
\hline 37 & family oriented & $\begin{array}{l}\text { famili orient friendli close team feel small type } \\
\text { compani knit busi tight group part warm worker } \\
\text { care friend commun cowork run felt owner home }\end{array}$ \\
\hline 14,61 & flexible & $\begin{array}{l}\text { work flexibl home schedul hour friendli time } \\
\text { great abil relax option fun remot pay casual easi } \\
\text { independ benefit good cowork comfort decent } \\
\text { freedom telecommut worker }\end{array}$ \\
\hline 50 & $\begin{array}{l}\text { demanding sched- } \\
\text { ule }\end{array}$ & $\begin{array}{l}\text { hour work long time flexibl stress expect pay } \\
\text { week weekend day retail overtim requir shift sea- } \\
\text { son lot job demand holiday busi night hard extra }\end{array}$ \\
\hline 55 & serenity & $\begin{array}{l}\text { work nice good friendli clean comfort pleasant } \\
\text { worker safe facil profession peopl physic healthi } \\
\text { campu modern quiet workplac peac calm neat } \\
\text { cowork beauti condit }\end{array}$ \\
\hline
\end{tabular}




\begin{tabular}{|c|c|c|}
\hline 16,74 & friendly & $\begin{array}{l}\text { work good friendli nice posit colleagu gener } \\
\text { peopl profession boss enjoy cooper pleasant col- } \\
\text { legu relax salari worker helpful support payment } \\
\text { upbeat workmat workplac relationship comfort }\end{array}$ \\
\hline 52,30 & collegial & $\begin{array}{l}\text { staff nice friendli good work peopl support } \\
\text { offic profession gener colleagu relax member lo- } \\
\text { cat warm worker excel pleasant collegi cowork } \\
\text { cooper pretti experienc ambianc knowledg }\end{array}$ \\
\hline $2,17,25,42,45$ & fun & $\begin{array}{l}\text { great make peopl work love benefit feel lot fun } \\
\text { amaz team enjoy smart worker awesom fantast } \\
\text { day meet friendli absolut thou friend nice cowork } \\
\text { product }\end{array}$ \\
\hline 10 & pet friendly & $\begin{array}{l}\text { great work friendli worker fun peopl dog amaz } \\
\text { eat love offic team famili cowork posit workplac } \\
\text { super bring pet kind beat camaraderi anim bee }\end{array}$ \\
\hline 43 & party & $\begin{array}{l}\text { fun activ event compani lot social team em- } \\
\text { ploye parti offic sport commun happi build in- } \\
\text { volv meet celebr perk outing regular includ en- } \\
\text { gag holiday monthli }\end{array}$ \\
\hline 53 & youth/energy & $\begin{array}{l}\text { fun young work peopl energet lot profession ex- } \\
\text { cit dynam offic vibrant creativ upbeat energi age } \\
\text { youth cool enthusiast colleg start motiv workforc } \\
\text { make love }\end{array}$ \\
\hline 8,39 & global & $\begin{array}{l}\text { opportun compani intern corpor divers local ex- } \\
\text { peri offic world american travel busi exposur } \\
\text { countri global japanes wide understand multi in- } \\
\text { dia client bank project speak learn }\end{array}$ \\
\hline $68,70,97$ & laid back & $\begin{array}{l}\text { back casual work laid relax friendli pretti dress } \\
\text { easi offic code fun stab wear nice fairli busi cool } \\
\text { gener comfort cowork peopl watch jean worker }\end{array}$ \\
\hline 92 & exploration & $\begin{array}{l}\text { learn lot great opportun thing experi work in- } \\
\text { tern respons curv challeng freedom hand stuff } \\
\text { exposur network alot resum chanc quickli scope } \\
\text { teach steep travel }\end{array}$ \\
\hline 0 & location & $\begin{array}{l}\text { offic locat beauti area citi campu live great build } \\
\text { park conveni downtown commut facil close site } \\
\text { central easi san view access work small town }\end{array}$ \\
\hline 40 & low pay & $\begin{array}{l}\text { pay low salari rais wage benefit job increas de- } \\
\text { cent promot stress minimum year bonus bonu } \\
\text { rate start poor hourli paid averag base worker } \\
\text { expect }\end{array}$ \\
\hline 83 & merger & $\begin{array}{l}\text { compani year past recent corpor improv start } \\
\text { acquisit made lost ago shift employe merger wors } \\
\text { coupl acquir continu move major due left declin } \\
\text { complet }\end{array}$ \\
\hline
\end{tabular}




\begin{tabular}{|c|c|c|}
\hline 32 & sharing & $\begin{array}{l}\text { idea open share employe encourag manag im- } \\
\text { prov collabor opinion inform feedback listen in- } \\
\text { nov heard suggest knowledg voic freedom ex- } \\
\text { press creativ team implement discuss posit }\end{array}$ \\
\hline 65 & open door & $\begin{array}{l}\text { open manag polici door friendli employe com- } \\
\text { mun mind transpar hr approach compani hon- } \\
\text { est support collabor close access revolv senior } \\
\text { feedback easili easi leadership inform }\end{array}$ \\
\hline 81 & open space & $\begin{array}{l}\text { offic work open space quiet cubicl bore dull bit } \\
\text { build moment distract wall floor desk comfort } \\
\text { cool small modern cube light depress loud area }\end{array}$ \\
\hline 64 & $\begin{array}{ll}\text { work hard/play } \\
\text { hard }\end{array}$ & $\begin{array}{l}\text { work hard play reward fun game enjoy mental } \\
\text { harder find recogn dedic type favorit worker beat } \\
\text { recognit role prepar push notic music acknowl- } \\
\text { edg parti }\end{array}$ \\
\hline 86 & perks & $\begin{array}{l}\text { free food lunch fun perk coffe snack gym drink } \\
\text { game offic friday beer room break lot park tabl } \\
\text { kitchen site cafeteria event parti cater }\end{array}$ \\
\hline 87 & politics & $\begin{array}{l}\text { corpor structur organ polit process flat larg hi- } \\
\text { erarchi highli organiz compani intern bit rigid } \\
\text { extrem organis hierarch lack bureaucrat system } \\
\text { conserv defin big tradit }\end{array}$ \\
\hline 36 & profit & $\begin{array}{l}\text { sale commiss sell competit product make cus- } \\
\text { tom base goal train pressur market potenti earn } \\
\text { money driven hit manag rep number target push } \\
\text { retail incent }\end{array}$ \\
\hline 46 & stable & $\begin{array}{l}\text { job work secur stabl easi posit stabil stress safe } \\
\text { employ satisfact bore enjoy steadi duti task re- } \\
\text { spons find descript repetit part titl fairli comfort }\end{array}$ \\
\hline 13 & size & $\begin{array}{l}\text { compani small big larg corpor feel size famili } \\
\text { firm smaller startup larger town part start organ } \\
\text { busi group bigger number agenc compar typic } \\
\text { resourc }\end{array}$ \\
\hline 94,82 & stress & $\begin{array}{l}\text { expect high work stress time pressur demand } \\
\text { turnov meet low task school deadlin rate work- } \\
\text { load energi project level manag perform complet }\end{array}$ \\
\hline 85 & supportive & $\begin{array}{l}\text { employe posit compani creat support manag en- } \\
\text { courag care healthi promot relationship build } \\
\text { engag happi maintain trust foster motiv work- } \\
\text { plac strive teamwork success genuin fellow }\end{array}$ \\
\hline 6 & $\begin{array}{l}\text { selection, } \\
\text { turnover, } \\
\text { promotion }\end{array}$ & $\begin{array}{l}\text { hire peopl compani fit posit job process promot } \\
\text { recruit interview person talent find intern experi } \\
\text { role candid type qualifi bring skill fire fill hr }\end{array}$ \\
\hline
\end{tabular}




\begin{tabular}{l|l|l}
\hline 67 & $\begin{array}{l}\text { individual excel- } \\
\text { lence }\end{array}$ & $\begin{array}{l}\text { peopl smart talent great work intellig motiv col- } \\
\text { labor passion incred colleagu group surround } \\
\text { amaz highli interest individu dedic driven bright } \\
\text { creativ hardwork young fantast }\end{array}$ \\
\hline 62 & goal oriented & $\begin{array}{l}\text { team goal success result achiev driven individu } \\
\text { orient motiv focus posit set common organ drive } \\
\text { succeed perform compani win person reward } \\
\text { competit collabor creat }\end{array}$ \\
\hline 1,59 & hostility & $\begin{array}{l}\text { poor work manag creat employe stress moral } \\
\text { hostil low neg bad extrem lack toxic terribl make } \\
\text { pay tens commun made staff uncomfort horribl } \\
\text { unhappi leadership }\end{array}$ \\
\hline 93 & fear & $\begin{array}{l}\text { fear creat manag employe toxic ceo neg constant } \\
\text { fire lead intimid blame hostil leadership micro- } \\
\text { manag distrust base staff bulli trust run senior } \\
\text { presid top }\end{array}$ \\
\hline 26 & gossip & $\begin{array}{l}\text { polit offic manag corpor extrem toxic bad hor- } \\
\text { ribl terribl neg unprofession gossip drama work- } \\
\text { plac boss backstab micromanag complet ego im- } \\
\text { matur charg petti worst run }\end{array}$ \\
\hline \hline 12 & vacation & $\begin{array}{l}\text { day time hour week work paid vacat shift leav } \\
\text { holiday year month sick night earli break end } \\
\text { start weekend home overtim schedul pm expect }\end{array}$ \\
\hline & vision & $\begin{array}{l}\text { compani leadership team strong mission ceo vi- } \\
\text { sion leader execut organ product creat posit } \\
\text { amaz core great solid senior inspir driven pas- } \\
\text { sion commit focus live }\end{array}$ \\
\hline
\end{tabular}




\section{References}

Adler, P. S. (2001). Market, hierarchy, and trust: The knowledge economy and the future of capitalism. Organization science, 12(2):215-234.

Anderson, T. and Bidwell, M. (2019). Outside insiders: Understanding the role of contracting in the careers of managerial workers. Organization Science.

Ashford, S. J., George, E., and Blatt, R. (2007). 2 old assumptions, new work: The opportunities and challenges of research on nonstandard employment. The Academy of Management Annals, $1(1): 65-117$.

Barley, S. S. and Kunda, G. (2004). Gurus, warm bodies and hired guns: Itinerant experts in the knowledge economy.

Bidwell, M. (2009). Do peripheral workers do peripheral work? comparing the use of highly skilled contractors and regular employees. ILR Review, 62(2):200-225.

Bidwell, M. (2010). Problems deciding: how the structure of make-or-buy decisions leads to transaction misalignment. Organization Science, 21(2):362-379.

Bidwell, M., Briscoe, F., Fernandez-Mateo, I., and Sterling, A. (2013). The employment relationship and inequality: How and why changes in employment practices are reshaping rewards in organizations. Academy of Management Annals, 7(1):61-121.

Bidwell, M. J. and Briscoe, F. (2009). Who contracts? determinants of the decision to work as an independent contractor among information technology workers. Academy of Management Journal, 52(6):1148-1168.

Blei, D. M., Ng, A. Y., and Jordan, M. I. (2003). Latent dirichlet allocation. Journal of machine Learning research, $3(\mathrm{Jan}): 993-1022$.

Briscoe, F., Wardell, M., and Sawyer, S. (2011). Membership has its privileges? contracting and access to jobs that accommodate work-life needs. ILR Review, 64(2):258-282.

Broschak, J. P., Davis-Blake, A., and Block, E. S. (2008). Nonstandard, not substandard: The relationship among work arrangements, work attitudes, and job performance. Work and Occupations, $35(1): 3-43$.

Cameron, K. S. and Quinn, R. E. (2011). Diagnosing and changing organizational culture: Based on the competing values framework. John Wiley \& Sons.

Cappelli, P. and Keller, J. R. (2013a). Classifying work in the new economy. Academy of Management Review, 38(4):575-596.

Cappelli, P. H. and Keller, J. R. (2013b). A study of the extent and potential causes of alternative employment arrangements. ILR Review, 66(4):874-901. 
Carley, K. (1991). A theory of group stability. American Sociological Review, 56:331-354.

Chatman, J. A. and O'Reilly, C. A. (2016). Paradigm lost: Reinvigorating the study of organizational culture. Research in Organizational Behavior, 36:199-224.

Corritore, M., Goldberg, A., and Srivastava, S. B. (2019). Duality in diversity: How intrapersonal and interpersonal cultural heterogeneity relate to firm performance. Administrative Science Quarterly, page 0001839219844175.

Davis-Blake, A., Broschak, J. P., and George, E. (2003). Happy together? how using nonstandard workers affects exit, voice, and loyalty among standard employees. Academy of Management Journal, 46(4):475-485.

Deal, T. E. and Kennedy, A. A. (1982). Corporate cultures. Addison Wesley Reading, MA.

Denison, D. R. and Mishra, A. K. (1995). Toward a theory of organizational culture and effectiveness. Organization Science, 6:204-223.

Denison, D. R., Spreitzer, G. M., et al. (1991). Organizational culture and organizational development: A competing values approach. Research in organizational change and development, $5(1): 1-21$.

Eliasoph, N. and Lichterman, P. (2003). Culture in interaction. American Journal of Sociology, 108(4):735-794.

Goldberg, A., Hannan, M. T., and Kovács, B. (2016). What does it mean to span cultural boundaries? variety and atypicality in cultural consumption. American Sociological Review, 81(2):215241.

Gordon, G. G. and DiTomaso, N. (1992). Predicting corporate performance from organizational culture. Journal of Management Studies, 29:783-798

Guest, D. (2004). Flexible employment contracts, the psychological contract and employee outcomes: an analysis and review of the evidence. International Journal of Management Reviews, $5(1): 1-19$.

Harrison, J. R. and Carroll, G. (2006). Culture and demography in organizations. Princeton University Press.

Hsu, G., Hannan, M. T., and Koçak, Ö. (2009). Multiple category memberships in markets: An integrative theory and two empirical tests. American Sociological Review, 74(1):150-169.

Kalleberg, A. L. (2000). Nonstandard employment relations: Part-time, temporary and contract work. Annual review of sociology, 26(1):341-365.

Kalleberg, A. L. (2003). Flexible firms and labor market segmentation: Effects of workplace restructuring on jobs and workers. Work and occupations, 30(2):154-175. 
Kalleberg, A. L., Reskin, B. F., and Hudson, K. (2000). Bad jobs in america: Standard and nonstandard employment relations and job quality in the united states. American sociological review, pages $256-278$.

Kalleberg, A. L. and Reynolds, J. (2003). Work attitudes and nonstandard work arrangements in the united states, japan, and europe. Nonstandard work in developed economies: Causes and consequences, pages 423-76.

Kotrba, L. M., Gillespie, M. A., Schmidt, A. M., Smerek, R. E., Ritchie, S. A., and Denison, D. R. (2012). Do consistent corporate cultures have better business performance? exploring the interaction effects. Human Relations, 65:241-262.

Kotter, J. P. and Heskett, J. L. (1992). Corporate Culture and Performance. Free Press, New York.

Kovács, B., Carroll, G. R., and Lehman, D. W. (2013). Authenticity and consumer value ratings: Empirical tests from the restaurant domain. Organization science, 25(2):458-478.

Kreps, D. M. (1996). Corporate culture and economic theory, pages 221-275. Oxford, UK: Oxford University Press.

Kristof-Brown, A. L., Zimmerman, R. D., and Johnson, E. C. (2005). Consequences of individuals'fit at work: A meta-analysis of person-job, person-organization, person-group, and person-supervisor fit. Personnel psychology, 58(2):281-342.

Kunda, G., Barley, S. R., and Evans, J. (2002). Why do contractors contract? the experience of highly skilled technical professionals in a contingent labor market. ILR Review, 55(2):234-261.

Lamont, M. and Molnár, V. (2002). The study of boundaries in the social sciences. Annual review of sociology, 28(1):167-195.

Lee, M. Y. and Edmondson, A. C. (2017). Self-managing organizations: Exploring the limits of less-hierarchical organizing. Research in organizational behavior, 37:35-58.

Liu, T., Makridis, C. A., Ouimet, P., and Simintzi, E. (2019). The distribution of non-wage benefits: Maternity benefits and gender diversity. Review of Financial Studies, R\&R.

Marinescu, I., Klein, N., Chamberlain, A., and Smart, M. (2018). Incentives can reduce bias in online reviews. NBER Working Paper.

Masten, S. E. (1988). A legal basis for the firm. Journal of Law, Economics, \& Organization, 4(1):181-198.

Mayer, K. J. and Nickerson, J. A. (2005). Antecedents and performance implications of contracting for knowledge workers: Evidence from information technology services. Organization Science, $16(3): 225-242$. 
Mobasseri, S., Goldberg, A., and Srivastava, S. B. (2019). What is cultural fit? The Oxford Handbook of Cognitive Sociology, page 305.

Morris, M. W., Chiu, C.-y., and Liu, Z. (2015). Polycultural psychology. Annual Review of Psychology, 66:631-659.

Nishii, L. H. (2013). The benefits of climate for inclusion for gender-diverse groups. Academy of Management Journal, 56(6):1754-1774.

O'Reilly, C. A., Caldwell, D. F., Chatman, J. A., and Doerr, B. (2014). The promise and problems of organizational culture: Ceo personality, culture, and firm performance. Group $\&$ Organization Management, 39(6):595-625.

O'Reilly, C. A., Chatman, J., and Caldwell, D. F. (1991). People and organizational culture: A profile comparison approach to assessing person-organization fit. Academy of Management Journal, $34: 487-516$.

O'Reilly, C. A. and Chatman, J. A. (1996). Culture as social control: Corporations, culture, and commitment. Research in organizational behavior, 18:157-200.

Pearce, J. L. (1993). Toward an organizational behavior of contract laborers: their psychological involvement and effects on employee co-workers. Academy of Management journal.

Pfeffer, J. and Baron, J. N. (1988). Taking the workers back out: Recent trends in the structuring of employment. Research in organizational behavior, 10(1988):257-303.

Rivera, L. A. (2012). Hiring as cultural matching: The case of elite professional service firms. American Sociological Review, 77:999-1022.

Rousseau, D. (1995). Psychological contracts in organizations: Understanding written and unwritten agreements. Sage publications.

Schneider, B., Ehrhart, M. G., and Macey, W. H. (2013). Organizational climate and culture. Annual Review of Psychology, 64:361-388.

Schwartz, S. H. (1999). A theory of cultural values and some implications for work. Applied psychology, 48(1):23-47.

Sørensen, J. B. (2002). The strength of corporate culture and the reliability of firm performance. Administrative Science Quarterly, 47:70-91.

Spreitzer, G. M., Cameron, L., and Garrett, L. (2017). Alternative work arrangements: Two images of the new world of work. Annual Review of Organizational Psychology and Organizational Behavior, 4:473-499.

Srivastava, S. B. and Banaji, M. R. (2011). Culture, cognition, and collaborative networks in organizations. American Sociological Review, 76:207-233. 
Srivastava, S. B., Goldberg, A., Manian, V. G., and Potts, C. (2017). Enculturation trajectories: Language, cultural adaptation, and individual outcomes in organizations. Management Science, 64(3):1348-1364.

Thorsteinson, T. J. (2003). Job attitudes of part-time vs. full-time workers: a meta-analytic review. Journal of Occupational and Organizational Psychology, 76(2):151-177.

Van Dyne, L. and Ang, S. (1998). Organizational citizenship behavior of contingent workers in singapore. Academy of management Journal, 41(6):692-703.

Williamson, O. E. (1981). The economics of organization: The transaction cost approach. American journal of sociology, 87(3):548-577. 